\title{
Assessing the migratory histories, trophic positions, and conditions of lake sturgeon in the St. Croix and Mississippi Rivers using fin ray microchemistry, stable isotopes, and fatty acid profiles
}

Jeffrey R. Ziegeweid ${ }^{1,2^{*}} \mathbb{D}$, Michelle R. Bartsch ${ }^{3} \mathbb{D}$, Lynn A. Bartsch ${ }^{3}$ (D) Steven J. Zigler ${ }^{3}$, Robert J. Kennedy ${ }^{3}$ and Seth A. Love ${ }^{4}$

\begin{abstract}
Background: Reproducing populations of invasive carps (Hypophthalmichthys spp.) could alter aquatic food webs and negatively affect native fishes in the Mississippi National River and Recreation Area (MISS) and the St. Croix National Scenic Riverway (SACN). However, proposed invasive carp barriers may also threaten populations of native migratory fishes by preventing movements of fish between rivers that are necessary for life history requirements. In this study, nonlethal chemical techniques were used to provide baseline data related to the condition, trophic position, and migratory histories of lake sturgeon (Acipenser fulvescens) captured in the Mississippi and St. Croix Rivers.

Results: Fish length and weight measurements and age estimates determined from pectoral fin rays demonstrated that lake sturgeon from the Mississippi River had greater lengths-at-age compared to sturgeon from the St. Croix River. However, length-weight relations were similar for sturgeon from the Mississippi and St. Croix Rivers. Lake sturgeon captured from different locations had distinguishable fatty acid signatures, and stable isotope analyses demonstrated that lake sturgeon from the Mississippi River generally feed at a higher trophic level than those in the St. Croix River. Strontium-to-calcium ratios (Sr:Ca) from fin ray cross sections indicated that sturgeon captured from the Mississippi River had higher Sr:Ca values than sturgeon captured from the St. Croix River, and natal origins and capture locations were not significantly different among sturgeon captured within individual rivers. Most sturgeon were captured in water with a similar Sr:Ca signature as their natal waters, indicating that there is some separation between populations of lake sturgeon in the St. Croix and Mississippi Rivers. However, Sr:Ca data indicated substantial variation in movement patterns among individual lake sturgeon, indicating that populations interact through migrations of individual fish between rivers.

Conclusions: Study results provide baseline condition and food web structure index data for assessing changes in lake sturgeon populations should invasive carps become established in these areas of the Mississippi and St. Croix Rivers. Controlled-exposure and telemetry studies would help verify and enhance the relations between Sr:Ca signatures in water and lake sturgeon pectoral fin rays to further assess mixing of sturgeons between rivers.
\end{abstract}

\footnotetext{
*Correspondence: jrziege@usgs.gov

${ }^{1}$ U.S. Geological Survey, California Water Science Center, 6000 J St, Placer

Hall, Sacramento, CA 95819, USA

Full list of author information is available at the end of the article
} original author(s) and the source, provide a link to the Creative Commons licence, and indicate if changes were made. The images or other third party material in this article are included in the article's Creative Commons licence, unless indicated otherwise in a credit line to the material. If material is not included in the article's Creative Commons licence and your intended use is not permitted by statutory regulation or exceeds the permitted use, you will need to obtain permission directly from the copyright holder. To view a copy of this licence, visit http://creativecommons.org/licenses/by/4.0/. 
Keywords: Fin ray microchemistry, Stable isotopes, Fatty acids, Lake sturgeon, St. Croix River, Mississippi River, National park, Strontium, Calcium

\section{Background}

Lake sturgeon (Acipenser fulvescens) are considered endangered, threatened, vulnerable or species of special concern throughout their range because of the effects of impeded migration from dams, habitat loss, pollution, and historical overharvest (Pikitch et al. 2005). Late sexual maturation, infrequent spawning, and long-distance migrations between habitats complicate lake sturgeon management and restoration efforts (Pikitch et al. 2005; Peterson et al. 2007). A few systems, such as the lower St. Croix River, Minnesota and Wisconsin, USA, contain self-sustaining lake sturgeon populations that support a limited harvest season (MNDNR 2021). The "lower St. Croix River" refers to the portion of the St. Croix River below a dam at St. Croix Falls, Wisconsin, USA, that acts as a barrier to fish migration. The "lower St. Croix River" will hereafter be referred to as the "St. Croix River."

Invasive carps (Hypophthalmichthys spp.) are threatening to establish populations in the St. Croix National Scenic Riverway (SACN) and Mississippi National River and Recreation Area (MISS) National Park Service (NPS) units (Ad Hoc Asian Carp Task Force 2011; Asian Carp Regional Coordinating Committee 2020). Established populations of invasive carps could threaten lake sturgeon and other native species of special concern through alteration of aquatic food webs (Irons et al. 2007). Current models indicate that invasive carps could cause a $30 \%$ reduction in biomass among lake sturgeon populations in the middle and upper Mississippi River systems (Kramer et al. 2019). However, proposed invasive carp barriers on the St. Croix and Mississippi Rivers (Ad Hoc Asian Carp Task Force 2011) also could reduce sustainability of lake sturgeon populations in the SACN and MISS by preventing lake sturgeon from migrating between critical spawning areas, juvenile nursery areas, and adult feeding areas (Auer 1996). Therefore, additional information would be useful to help determine condition, trophic position, habitat use, and migration patterns of lake sturgeon in the SACN and MISS prior to establishment of invasive carp populations or barriers to fish migration.

Analyses of lipids and fatty acids have been used in previous and ongoing studies that address the potential effects of invasive carp on native planktivorous fish in the SACN and MISS units (Fritts et al. 2018a; Gutreuter et al. 2011). Lipids and fatty acids are essential biomolecules in all living organisms as a primary source of energy and as building blocks for cell membranes and hormone-like substances (Arts et al. 2009). Certain groups of fatty acids are referred to as essential fatty acids (EFAs) because they only can be produced by autotrophs; therefore, higher-level organisms must obtain them directly from their diet. Essential fatty acids from algae transfer up the food web to filter-feeding invertebrates (Arts et al. 2009) that serve as food sources for fish such as lake sturgeon. Higher lipid and EFA content in fishes is often associated with greater rates of growth, survival, and reproduction (Tocher 2003). Therefore, established, reproducing populations of invasive carps in the SACN and MISS might indirectly reduce the health of lake sturgeon populations that are already in poor condition relative to other systems (Engel 1990; Ramsell 2010). For this reason, collecting lipid and fatty acid data for lake sturgeon in the SACN and MISS NPS units is important for establishing pre-invasive carp food web linkages and facilitating future comparisons to data from other systems.

Trophic positions and migration patterns to fulfill life history needs of lake sturgeon in the SACN and MISS are unclear. Engel (1990) used catch data to demonstrate that the lake sturgeon population in the lower St. Croix River contained a disproportionate number of juvenile fish and had lower growth rates and condition (i.e., weight for a given length) than lake sturgeon in many other systems. Growth and condition data collected by Ramsell (2010) using similar methods were similar to data collected by Engel (1990), but lake sturgeon weighed an average of 6 percent less than fish caught in the same system 20 years earlier. These length-weight relations might indicate poor, possibly declining environmental conditions or food availability for lake sturgeon in the St. Croix River. Furthermore, a juvenile-dominated population in the St. Croix River may indicate that lake sturgeon spawn in more suitable habitats in the St. Croix River and move to the Mississippi River as older juveniles or adults for more favorable habitat, including food resources. This migration hypothesis is supported by telemetry data that documented some long-distance movements of adult lake sturgeon into the Mississippi River (Engel 1990). However, telemetry studies are often constrained to a small number of larger fish because of cost and represent a short snapshot of time because of the battery life of transmitters. Therefore, development of additional techniques to nonlethally study migration histories and health of lake sturgeon in the St. Croix and Mississippi Rivers would be beneficial.

Trace metal microchemistry is becoming increasingly used to understand behavior in migratory fishes 
and to discriminate fish stocks among mixed populations (Wells et al. 2003; Crook and Gillanders 2006; Elsdon and Gillanders 2006; Pracheil et al. 2014). Calcified structures, such as lake sturgeon pectoral fin rays, are composed largely of biogenic calcium carbonate (Elsdon et al. 2008), but contain trace metals from the surrounding water that substitute for calcium (Ca), such as strontium ( $\mathrm{Sr}$ ) and barium (Ba). Because pectoral fin rays contain annuli that can be counted to determine the age of sampled fish, the timing of migratory events throughout the life of a lake sturgeon can be determined by comparing trace metal concentrations in interannular regions in cross sections of pectoral fin rays to trace metal concentrations of the waters inhabited by the fish. Pectoral fin rays can be sampled from lake sturgeon nonlethally and have been used successfully to identify river of origin for Scaphirhynchus species in the Missouri and Mississippi Rivers (Phelps et al. 2012). The geology of the watershed surrounding a river affects the concentrations of metals in the water (Palmer and Edmond 1992; Guay and Falkner 1998; Surge and Lohmann 2002; Elsdon and Gillanders 2004), so rivers with differing watershed geology will have different trace metal concentrations.

We conducted an exploratory evaluation of morphometric, fatty acid, stable isotope, and fin ray microchemistry data to examine the usefulness of these data for addressing information gaps relevant to the potential effects of invasive carps and management strategies on the trophic linkages and migration of lake sturgeon in the SACN and MISS NPS units. The specific aims of this study were to (1) compare relations among age, length, and weight for lake sturgeon captured in the St. Croix and Mississippi Rivers for initial evidence of mixed or separate populations of lake sturgeon, (2) establish baseline health and trophic position data for lake sturgeon in the St. Croix and Mississippi Rivers (SACN and MISS NPS units) using fatty acid and stable isotope analyses, respectively, (3) evaluate whether trace metal differences between the St. Croix and Mississippi Rivers are sufficient to serve as markers for determining migratory behavior and population linkages of lake sturgeon, and (4) if stable isotope and trace element differences are adequate, examine the frequency with which lake sturgeon move between the St. Croix and Mississippi Rivers. This study was initiated because Federal and State natural resource managers were concerned about the potential establishment of reproducing populations of invasive carps and the potential for carp-prevention strategies to have unintended negative effects on native species and ecosystems in the St. Croix and Mississippi Rivers (Ad Hoc Asian Carp Task Force 2011).

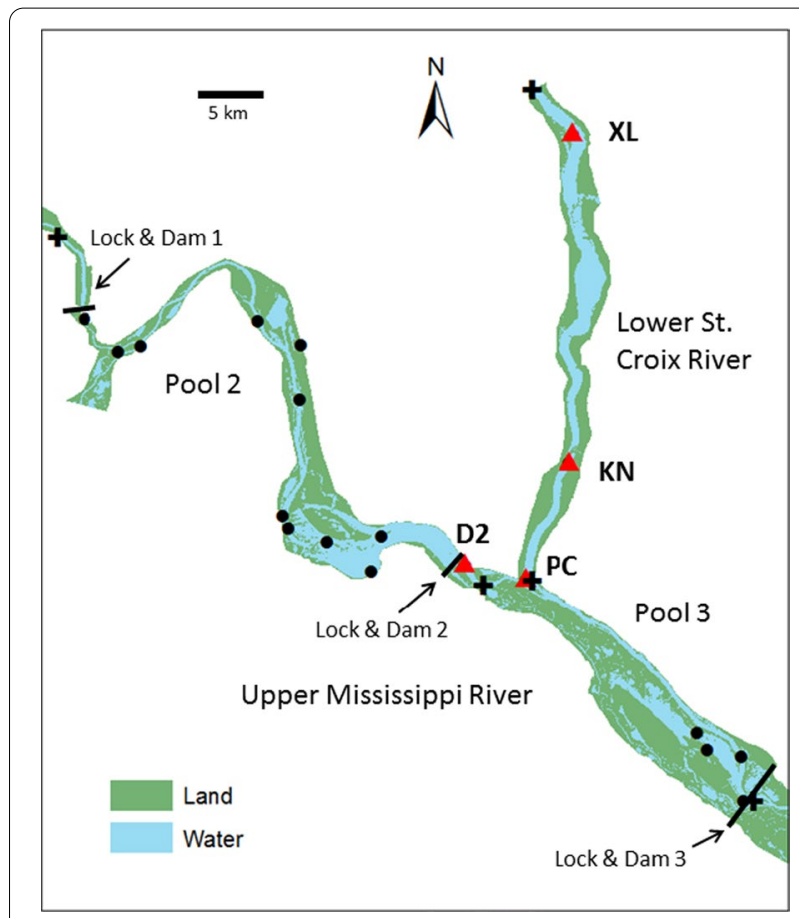

Fig. 1 Sampling locations (dot) for lake sturgeon and water quality (cross) in the St. Croix and Mississippi Rivers. Triangles denote locations where sturgeon where captured $(X \mathrm{~L}=$ near Xcel Energy Plant, Stillwater, Minnesota, USA; KN = near Kinnickinnic narrows; $\mathrm{PC}=$ near Prescott, WI, USA; D2 = tailwaters below Lock and Dam 2). The location of navigation dams on the Mississippi River are indicated by bars. Sampling locations for water quality in the Chippewa River (near Durand, Wisconsin) and Minnesota River (near Jordan, Minnesota) are not shown

\section{Methods}

Fish sampling and tissue collection

Lake sturgeon in the St. Croix and Mississippi Rivers were sampled using gill nets, trotlines and angling, and by-catch of commercial seining during September and October of 2014 (Fig. 1) following guidelines of Nickum et al. (2004). Total sampling effort was about 60 person-days not including cooperative sampling effort done by personnel from the Minnesota Department of Natural Resources (MNDNR) prior to this study that will be discussed in the next subsection. Gill netting and angling were done during daylight hours, but trotlines were also fished overnight. The gear types used at individual sampling sites varied depending on environmental conditions, presence of recreation boaters, and time constraints. Total length was measured for each lake sturgeon captured from the St. Croix $(n=15)$ and Mississippi $(n=6)$ Rivers. In addition, lake sturgeon captured in the St. Croix River were weighed by personnel from the MNDNR, but lake sturgeon collected from the Mississippi River were not weighed. 
Tissue collections were done non-lethally, because the lake sturgeon is an at-risk fish species. Fin rays were clipped from the left pectoral fin using previously published techniques (Phelps et al. 2012). Anterior dorsal muscle tissue was sampled using a sterile 3-mm dermal punch (Baker et al. 2004) from lake sturgeon sampled in each NPS unit (SACN and MISS). Muscle tissue samples were collected from all 6 lake sturgeon captured from the Mississippi River and from 13 of 15 lake sturgeon captured from the St. Croix River. Muscle tissue samples were not collected from two lake sturgeon captured in the St. Croix River to minimize stress to the fish because of concerns about their condition following capture. Wounds were disinfected using an antibacterial ointment and closed with surgical cyanoacrylate glue prior to release. All captured lake sturgeon were returned to the water and swam away under their own power. Tissue samples were immediately frozen in liquid nitrogen in the field and taken to the U.S. Geological Survey (USGS) Upper Midwest Environmental Sciences Center (UMESC) for storage at $-80{ }^{\circ} \mathrm{C}$ until analysis for stable isotopes and fatty acids.

\section{Archived fin rays}

Additional, archived fin rays for laboratory analyses were obtained from the MNDNR. Fin rays $(n=30)$ were collected from lake sturgeon captured by angling and trammel nets in the Lock and Dam 3 tailwater (Navigation Pool 4) of the Mississippi River during 2008. Fin rays were collected from lake sturgeon $(n=28)$ captured by angling, gill nets, and bycatch from commercial fishermen at various locations in the St. Croix River during surveys conducted in 2003-2004 and 2010-2013. All sturgeon captured by MNDNR personnel were measured for total length (TL) and weight at the time of capture.

\section{Age determination}

Archived fin rays from lake sturgeon captured in Navigation Pool 4 (near the tailwater of Lock and Dam No. 3) of the Mississippi River had been previously sectioned and aged by MNDNR staff. Staff from the Missouri Department of Conservation sectioned and aged fin rays of lake sturgeon captured in this study from the St. Croix and Mississippi (Navigation Pool 3) Rivers and of archived fin rays from the St. Croix River that were not aged previously. Ages were determined using methods defined in DeVries and Frie (1996). Briefly, two analysts independently estimated ages of lake sturgeon from annuli in fin ray cross-sections; they were not supplied any information about the lake sturgeon (e.g., size, weight, capture location). For each lake sturgeon, estimated age from analysts were compared and discrepancies were discussed until the analysts agreed upon a final estimated age.

\section{Lipid and fatty acid analyses}

Total lipids and fatty acid profiles were determined in the laboratory at UMESC. Tissue samples were freeze-dried at $-40{ }^{\circ} \mathrm{C}$ and ground to a homogeneous powder in liquid nitrogen. Methods for extraction and analysis of fatty acids followed Fritts et al. (2018b). Briefly, fatty-acid methyl esters (FAME) were obtained in a three-step process that included (1) extraction, (2) derivatization, and (3) quantification on a gas chromatograph (GC). The freeze-dried samples were extracted in a chloroform:methanol solution using a pressurized liquid extraction (PLE) system (Dionex, Accelerated Solvent Extraction system (ASE), model 200, Sunnyvale, California, USA) and centrifuged at 2,900 rpm to remove nonlipid material. Two 100- $\mu \mathrm{L}$ aliquots were removed, dried, and weighed to measure total lipid content. The remaining sample was suspended in hexane and derivatized with $1 \% \mathrm{H}_{2} \mathrm{SO}_{4} /$ methanol. The methylated lipid extract was analyzed by gas chromatography (Agilent Model 6890, Wilmington, Delaware, USA) using a Supelco 2560 capillary column $(100 \mathrm{~m}, 0.25-\mathrm{mm}$ inner diameter and a $0.2-\mu \mathrm{m}$ film thickness) and measured by a flame-ionization detector. Fatty-acid methyl esters were identified by comparison of their retention times with known standards (37-component FAME mix, \#47885-U, bacterial acid methyl ester mix Supleco \#47080-U, and additional fatty acid standards were added to expand the range of quantifiable fatty acids; Sigma-Aldrich, St. Louis, Missouri, USA) and quantified with reference calibration curves. The profiles for each sample consisted of the concentrations of 47 individual fatty acids and total lipid content.

\section{Stable isotope analyses}

Chemical analyses of carbon and nitrogen stable isotopes were conducted at the Colorado Plateau Stable Isotope Laboratory at Northern Arizona University. Stable isotope ratios of carbon $\left({ }^{13} \mathrm{C} /{ }^{12} \mathrm{C}\right)$ and nitrogen $\left({ }^{15} \mathrm{~N} /{ }^{14} \mathrm{~N}\right)$ were determined for lake sturgeon with a Thermo-Finnigan Delta plus Advantage gas isotope-ratio mass spectrometer interfaced with a Costech Analytical ECS4010 elemental analyzer (or equivalent instruments). Stable isotope $\left(\delta^{13} \mathrm{C}\right.$ and $\left.\delta^{15} \mathrm{~N}\right)$ data were expressed relative to Vienna Pee Dee Belemnite (VPDB) and AIR standards for carbon and nitrogen, respectively. Stable isotope ratios of samples were reported as per mil (\%) relative to standards. Three tissue samples were split into three parts and processed as blind replicates as a measure of quality assurance.

Nitrogen and carbon isotope ratios were used to assess relative vertical and horizontal trophic positions (Hecky 
and Hesslein 1995; Vander Zanden et al. 2000; Jardine et al. 2006) of lake sturgeon in the St. Croix and Mississippi Rivers. Adult freshwater mussels are primary consumers of pelagic algae that integrate isotope ratios of their more isotopically variable food source. The greater the mean difference in lake sturgeon and freshwater mussel $\delta^{15} \mathrm{~N}$, the greater the relative vertical trophic position of lake sturgeon. The greater the mean difference in lake sturgeon and freshwater mussels $\delta^{13} \mathrm{C}$, the more important benthic carbon sources than pelagic carbon sources are to lake sturgeon (Bruestle et al. 2019). Stable isotope data from freshwater mussels (Amblema plicata, foot tissue) sampled in this system were available from another study conducted in 2013 and 2014 (Fritts et al. 2018b) for Stillwater, Minnesota, USA, upstream from the Xcel Energy Plant, near Kinnickinnic narrows in the St. Croix River, and near River Lake within Pool 2 of the Mississippi River). The trophic positions of lake sturgeon captured near Prescott, Wisconsin, USA were estimated using $A$. plicata (foot tissue) as the baseline organism near the same location within the lower St. Croix River (Zigler et al. 2021). Lake sturgeon dorsal muscle tissues were used to calculate their trophic position using the following equation (Bruestle et al. 2019):

$$
\text { Trophic position }=\left(\frac{\delta^{15} N_{\text {consumer }}-\delta^{15} N_{\text {baseline }}}{3.0}\right)+2.0
$$

where $\delta^{15} N_{\text {consumer }}$ is the stable nitrogen isotopic signature of a given lake sturgeon, $\delta^{15} N_{\text {baseline }}$ is the stable nitrogen isotopic signature of the site-specific $A$. plicata baseline organism, 3.0 is the trophic enrichment factor relevant to lake sturgeon, and 2.0 is the trophic position of the baseline organism.

\section{Water collection and analyses}

Water was sampled for trace elements including $\mathrm{Sr}$ and $\mathrm{Ca}$ at three locations in the Mississippi River Navigation Pools 1 (USGS station 05288930), 3 (USGS station 05331580), and 4 (USGS station 05344980) and three locations in the St. Croix River near Franconia, Minnesota (USGS station 05340540), Stillwater, Minnesota (USGS station 05341550), and Prescott, Wisconsin (USGS station 05344490) to demonstrate that the rivers had different water Sr:Ca values. All water-sampling locations except USGS station 05340540 (farther upstream on St. Croix River) are shown in Fig. 1. Water samples were also collected at the Minnesota River near Jordan, Minnesota (USGS station 05330000), and at the Chippewa River near Durand, Wisconsin (USGS station 05369500), but these sites are not shown in Fig. 1, and data from these sites are not discussed in this paper. Samples were collected seasonally (spring, summer, and fall) in 2015 using standardized protocols. Additional information on the collection methods, analyses, and results of water analyses can be found in Ziegeweid et al. (2018).

\section{Fin ray laboratory analyses}

Archived and newly collected lake sturgeon pectoral fin rays were analyzed for $\mathrm{Sr}$ to $\mathrm{Ca}$ ratios $(\mathrm{Sr}: \mathrm{Ca})$ using laser ablation inductively coupled plasma mass spectrometry (ICPMS) following Phelps et al. (2012). All fin ray preparation and laser ablation analyses were completed by staff from the Missouri Department of Conservation. Fin rays were dried and thin sectioned with a Buehler ISOMET low-speed saw (Buehler Inc., Lake Bluff, Illinois, USA). Rays too small for immediate sectioning were embedded in Epo-Fix epoxy (Electron Microscopy Science Inc., Hatfield, Pennsylvania, USA) prior to sectioning. Sectioned rays were sanded with 800 - and 1000 -grit siliconcarbide sandpaper and polished with 5- $\mu \mathrm{m}$ lapping film (Ted Pella Inc., Redding, California, USA) to produce a smooth, 1.2-mm thick section. Deionized water was used throughout the process to minimize trace metal contamination. Samples were not sonicated because of potential sample damage and increased cleaning time (Gover et al. 2014). Fin ray sections were mounted on acid-washed glass slides with double-sided tape and stored in sealed, acid-washed polypropylene petri dishes until analysis.

Fin ray trace element analysis was conducted at the University of Massachusetts-Boston Environmental Analytical Facility (UMASS EAF) using a Perkin-Elmer DRC II ICPMS and a CETAC Technologies LSX-500 laser ablation system. Fin ray tissue was sampled using laser ablation ICPMS along radial transects across cross sections. The laser parameters were as follows: energy level $=75 \%$, pulse rate $=10 \mathrm{~Hz}$, beam diameter $=25 \mu \mathrm{m}$, scan rate $=5 \mu \mathrm{m} / \mathrm{s}$. A standard developed by the USGS (MACS-3) was analyzed by laser ablation every 12-18 samples to adjust for possible instrument drift (Wilson et al. 2008). Each fin ray ablation was preceded by a 30-s gas blank. Isotopic counts per second (cps) were converted to elemental concentrations after accounting for matrix, drift effects, and gas blank (Porreca et al. 2016) using CETAC Technologies GeoPro software (version 2.1, Omaha, Nebraska, USA). All analyzed fin rays had Sr and $\mathrm{Ca}$ concentrations above gas blank levels.

Calcium has five stable isotopes with varying abundances (Schiller et al. 2012). Consequently, ${ }^{46} \mathrm{Ca}$ was selected as an internal standard because of low natural abundances, and ${ }^{43} \mathrm{Ca}$ was used to quantify calcium concentrations because of relatively high abundances compared to ${ }^{46} \mathrm{Ca}$ (Schiller et al. 2012). Strontium concentrations were quantified using the ${ }^{86} \mathrm{Sr}$ isotope. Ultimately, the $\mathrm{Sr}: \mathrm{Ca}$ values reported are total elemental concentrations based on the relative abundances of ${ }^{86} \mathrm{Sr}$ 


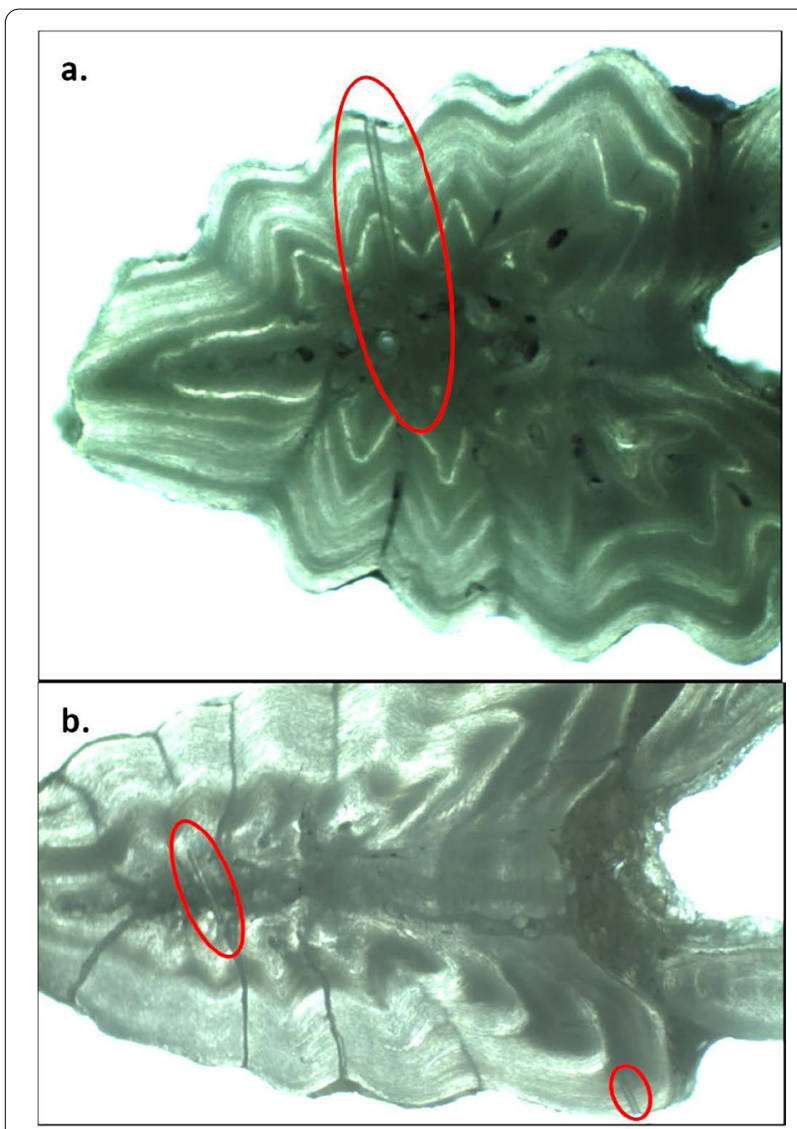

Fig. 2 Photographs illustrating the laser ablation analyses using full "core to edge" transects corresponding to November 2015 (a) and smaller separate "core" and "edge" transects corresponding to March 2016 (b). Red circles highlight ablation lines

and ${ }^{43} \mathrm{Ca}$. Fin ray calcium concentrations were set at $27 \%$ according to Phelps et al. (2012) and Porreca et al. (2016). The GeoPro software was used to ensure that analyte sensitivities were above zero, offsets were close to zero, and measured concentrations of standards were within $10 \%$ of actual concentrations (Porreca et al. 2016). The GeoPro software also automatically applied corrections to $\mathrm{Sr}$ and $\mathrm{Ca}$ concentrations measured from fin ray cross sections based on measured standards (Phelps et al. 2012; Porreca et al. 2016).

Concentrations of $\mathrm{Sr}$ and $\mathrm{Ca}$ sampled by laser ablation from transects across sections of lake sturgeon pectoral fin rays were analyzed in two groups. The first group of fin rays (group 1), analyzed in November 2015, included lake sturgeon sampled during this study from the Mississippi (Navigation Pool 3; $n=6$ ) and the St. Croix River $(n=15)$ and archived fin rays from the St. Croix River collected by MNDNR $(n=28)$. Fin ray cross sections were analyzed by ablating a complete transect extending from the fin ray core to the fin ray edge (Fig. 2a).
However, imperfections in fin ray cross sections caused data quality concerns about Sr:Ca values, and difficulties positioning the laser occasionally caused the analyst to miss the fin ray core (representing natal origins) or stop the laser before reaching the fin ray edge (representing capture locations). When such difficulties occurred, the analyst noted the quality or missing data issues following the sampling runs, and these fin ray cross sections were excluded from the analysis comparing sample populations from the St. Croix and Mississippi Rivers.

Only core and edge data classified as "good" (prior to completing any statistical analyses) were included in statistical analyses related to natal origins and capture locations, respectively. Natal origin and capture location ablation data were classified as "good" if the laser ablation analyst noted that the core and edge of the fin ray, respectively, were adequately sampled by the laser ablation transect and if the laser did not encounter cracks or imperfections in the fin-ray cross section. Notes from the laser ablation analyst were verified using photographs of ablated fin-ray cross sections taken with a digital camera mounted to a microscope. The number of "good" natal origin and capture location data points for each sampling location was insufficient to make comparisons between rivers and among capture locations. Therefore, a subset of fin ray cross sections $(n=13)$ were reanalyzed in March 2016 to increase the number of "good" data points from each river and facilitate additional comparisons of $\mathrm{Sr}$ :Ca for lake sturgeon captured from the Mississippi and St. Croix Rivers.

A second group of fin rays (group 2) was analyzed in March 2016 and consisted of the archived fin rays from lake sturgeon captured in the Mississippi River (Navigation Pool $4 ; n=30$ ) and the subset of group 1 cross sections requested for re-analysis $(n=13)$. However, cross sections from group 2 were analyzed with two sets of smaller transects to obtain data focused on the fin ray core and fin ray edge rather than a single transect from the fin ray core to the fin ray edge because of limited availability of the laser ablation analyst and instrument (Fig. 2b). Results from fin ray samples from both groups 1 and 2 were analyzed and compared to evaluate variability. Methods for comparing fin ray $\mathrm{Sr}$ :Ca measured in groups 1 and 2 are described in the next subsection. Only core and edge data classified as "good" by the laser ablation analyst were included in statistical analyses related to natal origins and capture locations, respectively. For fin ray cross sections with "good" data from analyses in both group 1 (November 2015) and group 2 (March 2016), only data from group 2 were used in comparative analyses of sample populations among combinations of river and fin ray portion. 


\section{Fin ray data analyses}

The primary focus of laser ablation analyses was to measure $\mathrm{Sr}: \mathrm{Ca}$ ratios of core and edge portions of fin ray cross sections associated with natal origins and capture locations, respectively. Therefore, data were extracted from ablation sampling points along transects for each fin ray that represented growth associated with natal and capture locations. Notes from the laser ablation analyst were used to identify $\mathrm{Sr}$ :Ca ratios within the "core" portions of pectoral fin ray cross sections that corresponded to natal origins. Multiple ablation points from each fin ray core were used to compute mean natal Sr:Ca values for each captured lake sturgeon. Means and standard errors from core portions of fin ray cross sections from individual lake sturgeon captured in the St. Croix and Mississippi Rivers were used to examine variability in $\mathrm{Sr}: \mathrm{Ca}$ associated with natal origins of lake sturgeon captured in each river. The last two laser ablation transect points closest to the fin ray edge were assumed to represent the most recent growth associated with capture locations of the lake sturgeon and were characterized as the mean $\mathrm{Sr}: \mathrm{Ca}$ concentrations. Standard error could not be calculated because only two data points were used to represent the $\mathrm{Sr}: \mathrm{Ca}$ signature of the capture location. Therefore, the range of the two data points was used to examine variability in Sr:Ca signatures among individual fish.

$\mathrm{Sr}: \mathrm{Ca}$ values associated with core (natal origins) and edge (capture locations) were compared for a subset $(n=7)$ of pectoral fin ray cross sections that were analyzed in both group 1 (November 2015) and group 2 (March 2016). For five of the fin rays, only core (natal) portions were compared between the two analysis periods because the original ablation analysis did not sample fin ray material close enough to the edge of the cross section. For the other two fin rays, the results from core and edge (capture) portions were compared. Core and edge $\mathrm{Sr}: \mathrm{Ca}$ comparisons were combined into a single dataset $(n=9)$, and further examination demonstrated a systematic bias between the data from the two analysis periods. The Sr:Ca values obtained in November 2015 were consistently higher than those obtained in March 2016. The laser ablation analyst was consulted, and the data were reviewed, but the reason for the differences could not be determined. A review of the standard curves and standard reference materials did not indicate a quality control issue during either batch of analyses. Therefore, a correction was developed to remove the observed systematic bias and increase the comparability of data obtained from the two analysis groups (Callister et al. 2006; Kimura et al. 2013). The mean ratio (group 2: group 1) was used as a multiplicative correction that was applied to group 1 results, and simple linear regression analyses were used to verify significant linear relations between groups 1 and
2. One "core" fin ray portion was excluded from the dataset used to calculate the multiplicative correction $(n=8)$ as an outlier based on comparisons of corrected and uncorrected relative percent differences and results of linear regression analyses. The multiplicative correction is described in more detail in the Results section.

\section{Statistical analyses}

Age, length, and weight data for sample populations of lake sturgeon were compared graphically between the Mississippi $(n=30)$ and St. Croix Rivers $(n=34)$ using boxplots. Statistical comparisons of age, length, and weight data were not completed because of concerns related to small sample sizes, wide ranges in sampling dates (2003-2014), sampling using multiple gear types, and nonrandomized sampling designed to target lake sturgeon in known or suspected habitats. Furthermore, age, length, and weight data were collected and compared as ancillary information used to inform interpretations of fatty acid, stable isotope, and laser ablation data consisting of small sample sizes from highly variable river systems.

All statistical analyses were completed using standard commands in the $\mathrm{R}$ environment (version 3.0.4; $\mathrm{R}$ Core Team 2014) or with $\mathrm{JMP}^{\odot}$ statistical software (version 14 , SAS Institute Inc., Cary, North Carolina, USA). A level of significance $(\alpha)$ of 0.05 was used for all statistical tests. Hierarchical cluster analysis using the Ward's minimum variance method was performed on standardized percent fatty acid concentration data from lake sturgeon tissue samples $\left(\mathrm{JMP}^{\odot}\right.$ version 14, SAS Institute Inc., Carry, North Carolina, USA). Descriptive statistics and graphics of lipids, fatty acids and stable isotopes of nitrogen and carbon data were also generated using JMP॰ software (version 14).

Comparisons among natal and capture location $\mathrm{Sr}: \mathrm{Ca}$ values for fin rays from lake sturgeon captured in the Mississippi and St. Croix Rivers were made by dividing "good" Sr:Ca values into four groups: Mississippi-capture $(n=30)$, Mississippi-natal $(n=31)$, St. Croix-capture $(n=22)$, and St. Croix-natal $(n=30)$. A one-way analysis of variance (ANOVA) test with pairwise comparisons using Tukey's Honestly Significant Difference (HSD) tests (Ott and Longnecker 2010) was completed in the R environment (version 3.0.4; R Core Team 2014). After identifying statistically significant differences in edge $\mathrm{Sr}: \mathrm{Ca}$ data associated with capture locations from lake sturgeon for the two rivers, 95\% confidence limits for edge $\mathrm{Sr}: \mathrm{Ca}$ data associated with each river were used during graphical comparisons of full "core to edge" laser ablation transect data obtained from pectoral fin rays analyzed in group 1 (November 2015). 
Table 1 Capture and morphometric data for lake sturgeon from the St. Croix and Mississippi Rivers

\begin{tabular}{|c|c|c|c|c|c|c|c|c|}
\hline Fish ID & MN-DNR Pit tag & River & Location $^{a}$ & Capture date & Age (years) & $\begin{array}{l}\text { Total Length } \\
(\mathrm{mm})\end{array}$ & Weight (kg) & $\begin{array}{l}\text { Muscle } \\
\text { sample }^{c}\end{array}$ \\
\hline 94433 & 900118001527746 & St. Croix & $\mathrm{KN}$ & $9 / 15 / 2014$ & 24 & 1352 & 13.25 & Y \\
\hline 40115 & 900118001582597 & St. Croix & $\mathrm{KN}$ & $9 / 15 / 2014$ & 11 & 1123 & 5.9 & Y \\
\hline 94434 & 900118001548859 & St. Croix & $\mathrm{KN}$ & $9 / 15 / 2014$ & 23 & 1307 & 12.45 & Y \\
\hline 94435 & 900118001583442 & St. Croix & PC & $9 / 15 / 2014$ & 10 & 882 & 3.5 & Y \\
\hline 94440 & 900118001580878 & St. Croix & PC & $9 / 16 / 2014$ & 22 & 1384 & 8.9 & Y \\
\hline 94439 & 900118001582948 & St. Croix & PC & $9 / 16 / 2014$ & 10 & 964 & 3.8 & Y \\
\hline 94436 & 900118001529433 & St. Croix & $\mathrm{KN}$ & 9/16/2014 & 10 & 975 & 4.41 & Y \\
\hline 94438 & 900118001529426 & St. Croix & $\mathrm{KN}$ & $9 / 16 / 2014$ & 12 & 1031 & 5.1 & Y \\
\hline 94437 & 900118001579692 & St. Croix & KN & 9/16/2014 & 15 & 1204 & 9.94 & Y \\
\hline 94441 & 900118001581884 & St. Croix & $X L$ & $9 / 17 / 2014$ & 8 & 690 & 1.15 & Y \\
\hline 94442 & 900118001527112 & St. Croix & $X L$ & $9 / 17 / 2014$ & 8 & 787 & 2.15 & Y \\
\hline 94443 & 900118001527559 & St. Croix & $X \mathrm{~L}$ & $9 / 17 / 2014$ & 16 & 1160 & 8.9 & Y \\
\hline 94444 & 900118001527313 & St. Croix & $X L$ & $9 / 17 / 2014$ & 4 & 418 & 0.24 & Y \\
\hline 94445 & 900118001583431 & St. Croix & $X L$ & $9 / 17 / 2014$ & 7 & 558 & 1.05 & $N$ \\
\hline 94446 & 900118001583375 & St. Croix & $X \mathrm{~L}$ & $9 / 17 / 2014$ & 7 & 676 & 1.35 & $N$ \\
\hline P3- $-01^{d}$ & & Mississippi & D2 & 10/20/2014 & 14 & 1150 & & Y \\
\hline$P 3-02^{b d}$ & & Mississippi & D2 & $10 / 21 / 2014$ & 11 & 1260 & & Y \\
\hline P3- $03^{\text {bd }}$ & & Mississippi & D2 & $10 / 21 / 2014$ & 16 & 1370 & & Y \\
\hline P3-04 ${ }^{\text {bd }}$ & & Mississippi & D2 & $10 / 21 / 2014$ & 24 & 1250 & & Y \\
\hline P3-05 ${ }^{\text {bd }}$ & & Mississippi & D2 & $10 / 21 / 2014$ & 14 & 1020 & & Y \\
\hline P3-06 ${ }^{\text {bd }}$ & & Mississippi & D2 & $10 / 23 / 2014$ & 13 & 1150 & & Y \\
\hline
\end{tabular}

Graphical representations of full "core to edge" laser ablation transect $\mathrm{Sr}$ :Ca data are provided for all $49 \mathrm{fin}$ ray cross sections analyzed in group 1 (November 2015; Zigler et al. 2021). This group included fin rays from 21 lake sturgeon captured by UMESC ( 15 from St. Croix River, 6 from Mississippi River) in 2014 and 28 lake sturgeon captured in the St. Croix River by the MNDNR (2003-2004 and 2010-2014). For each laser ablation transect, $\mathrm{Sr}$ :Ca values obtained every $20 \mu \mathrm{m}$ were connected using smoothed lines to connect the data points along the transect. The upper and lower 95\% confidence limits of "good" edge Sr:Ca data from the St. Croix and Mississippi Rivers also were plotted as horizontal lines on the graphs and used to qualitatively evaluate whether measured $\mathrm{Sr}: \mathrm{Ca}$ concentrations in fin ray cross sections indicated possible movement between the two rivers.

\section{Results}

Fifteen lake sturgeon were captured in the St. Croix River and six were captured in the Mississippi River (Navigation Pool 3; Table 1). Lake sturgeon were not captured in Navigation Pool 2 of the Mississippi River despite more than one week of effort by field crews. Captured lake sturgeon ranged from 418 to $1384 \mathrm{~mm}$ total length (mean $\mathrm{TL}=967 \mathrm{~mm}$ ) in the St. Croix River and ranged from 1020 to $1370 \mathrm{~mm}$ total length (mean $\mathrm{TL}=1200 \mathrm{~mm}$ ) in Navigation Pool 3. Estimated ages of captured lake sturgeon ranged from 4 to 24 years in the St. Croix River and from 11 to 21 years in Navigation Pool 3 of the Mississippi River (Table 1). Data associated with lake sturgeon captured in this study are published in Zigler et al. (2021).

\section{Lake sturgeon morphometrics between rivers}

Morphometrics of lake sturgeon captured in this study and associated with archived fin rays used in study analyses from the St. Croix $(n=34)$ and Mississippi $(n=30)$ Rivers were compared graphically using boxplots to identify potential biases on study results and further examine similarities and differences of lake sturgeon from the two rivers (Fig. 3). Ranges of ages, lengths, and weights of captured lake sturgeon included in this study were greater in the St. Croix River than in the Mississippi River (Fig. 3). However, lake sturgeon from the Mississippi River were estimated to have greater lengths at age 

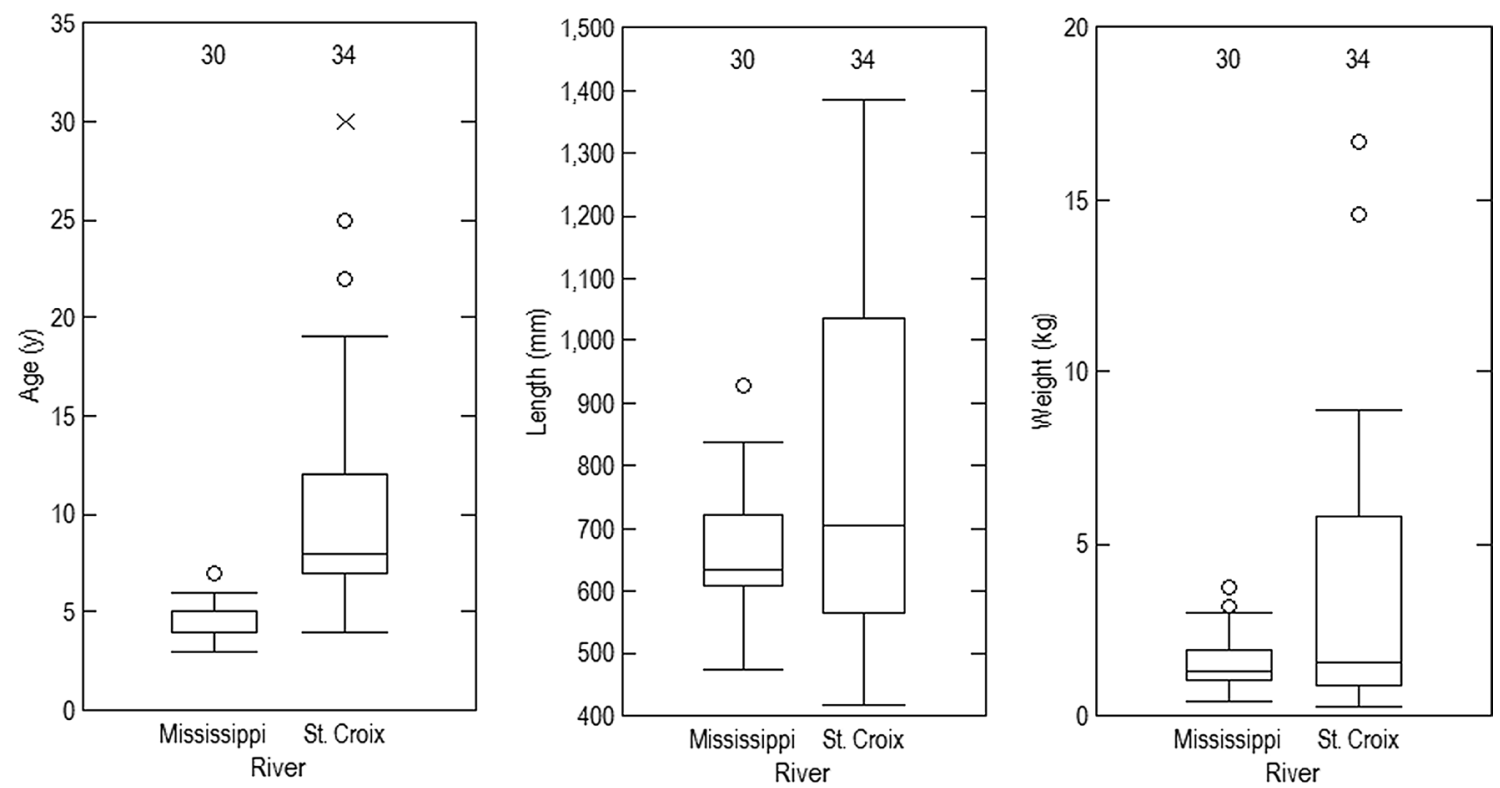

Fig. 3 Boxplots illustrating distributions of age, length, and weight data for lake sturgeon captured in the Mississippi $(n=30)$ and St. Croix ( $n=34)$ Rivers. Boxes represent the interquartile ranges, with center lines in representing median values and the upper and lower ends of the boxes representing the 75th and 25th percentiles, respectively. Whiskers represent values within 1.5 times of the interquartile range, either above the 75 th percentile or below the 25th percentile. Values plotted as open circles represent values within 3 times the interquartile range

compared to sturgeon from the St. Croix River (Fig. 4a). Finally, length-weight relations were similar for sturgeon captured in the Mississippi and St. Croix Rivers (Fig. 4b). Lake sturgeon morphometric data from lake sturgeon captured in this study and for lake sturgeon associated with archived pectoral fin rays used in study analyses are published in Zigler et al. (2021) and included in Additional file 1 .

\section{Lipids and fatty acids}

The mean total lipid content, in percent dry weight (\% $\mathrm{dw}$ ), for lake sturgeon was $15.6 \%$ (range 8.8 to $32.9 \%$, $n=13$ ) in the St. Croix River and $18.7 \%$ (range 16.4 to $22.0 \%, n=6)$ in the Mississippi River. The total lipid content was correlated with total length and age of lake sturgeon ( $r=0.63, p=0.004$, and $r=0.62, p=0.004$, respectively). Fatty acid concentration data $(\mathrm{mg} / \mathrm{g} \mathrm{dw})$ for lake sturgeon captured within the St. Croix River and upper Mississippi River are available in Zigler et al. (2021). Lake sturgeon from the St. Croix River generally had a higher percentage of the essential fatty acids (EFAs) linoleic acid, LIN (2.4\% C18:2n6c, range 1.5 to $2.9 \%)$, arachidonic acid, ARA (7.4\% C20:4n6, range 2.8 to $15.3 \%$ ), eicosapentaenoic acid, EPA (8.3\% C20:5n3, range 5.7 to 14.7\%), and docosahexanenoic acid, DHA (7.5\% C22:6n3, range 3.3 to $13.9 \%$ ) than lake sturgeon from the Mississippi River (LIN 2.2\%, range 1.6 to $2.7 \%$; ARA 4.4\%, range 3.7 to $5.8 \%$; EPA 6.6\%, range 5.4 to $8.2 \%$; DHA $6.5 \%$, range
2.9 to $10.1 \%$; Fig. 5). In contrast, lake sturgeon from the Mississippi River had higher percentages of $\alpha$-linolenic acid, ALA (2.2\% C18:3n3, range 1.5 to $3.1 \%)$ compared to lake sturgeon from the St. Croix River (ALA 1.8\%, range 0.81 to $2.9 \%$; Fig. 5 ).

Percentages of other fatty acids were compared between lake sturgeon captured from the St. Croix and Mississippi Rivers. Lake sturgeon from the St. Croix River generally had a higher percentage of the following saturated fatty acids (SAFAs): myristic acid, C14:0 (0.75\%, range 0.07 to 1.9$)$; margaric acid, $\mathrm{C} 17: 0(0.71 \%$, range 0.39 to $1.1 \%)$; and stearic acid, C18:0 (4.0\%, range 2.3 to $6.1 \%)$. In contrast, lake sturgeon from the Mississippi River generally had a higher percentage of pentadecylic acid, C15:0 (0.38\%, range 0.25 to $0.49 \%)$ and palmitic acid, C16:0 (18.2\%, range 16.1 to $19.5 \%$; Fig. 5). Lake sturgeon from the Mississippi River generally also had a higher percentage of the monounsaturated fatty acids (MUFAs) palmitoleic acid, C16:1n7 (7.3\%, range 6.3 to $8.2 \%)$; oleic acid, C18:1n9c (28.6\%, range 25.3 to $33.5 \%)$; and eicosenoic acid, C20:1n9 (0.92\%, range 0.71 to $1.3 \%)$; however, lake sturgeon from the St. Croix River had a higher percentage of nervonic acid, $\mathrm{C} 24: 1 \mathrm{n} 9(0.15 \%$, range 0.07 to $0.22 \%$, Fig. 5). Lake sturgeon from the St. Croix River generally had a higher percentage of the following polyunsaturated fatty acids (PUFAs): $\gamma$-linolenic acid, C18:3n6 $(0.20 \%$, range 0.07 to $0.33 \%)$; stearidonic acid, C18:4n3 (0.71\%, range 0.30 to $1.4 \%)$; dihomo- $\gamma$-linolenic acid, 


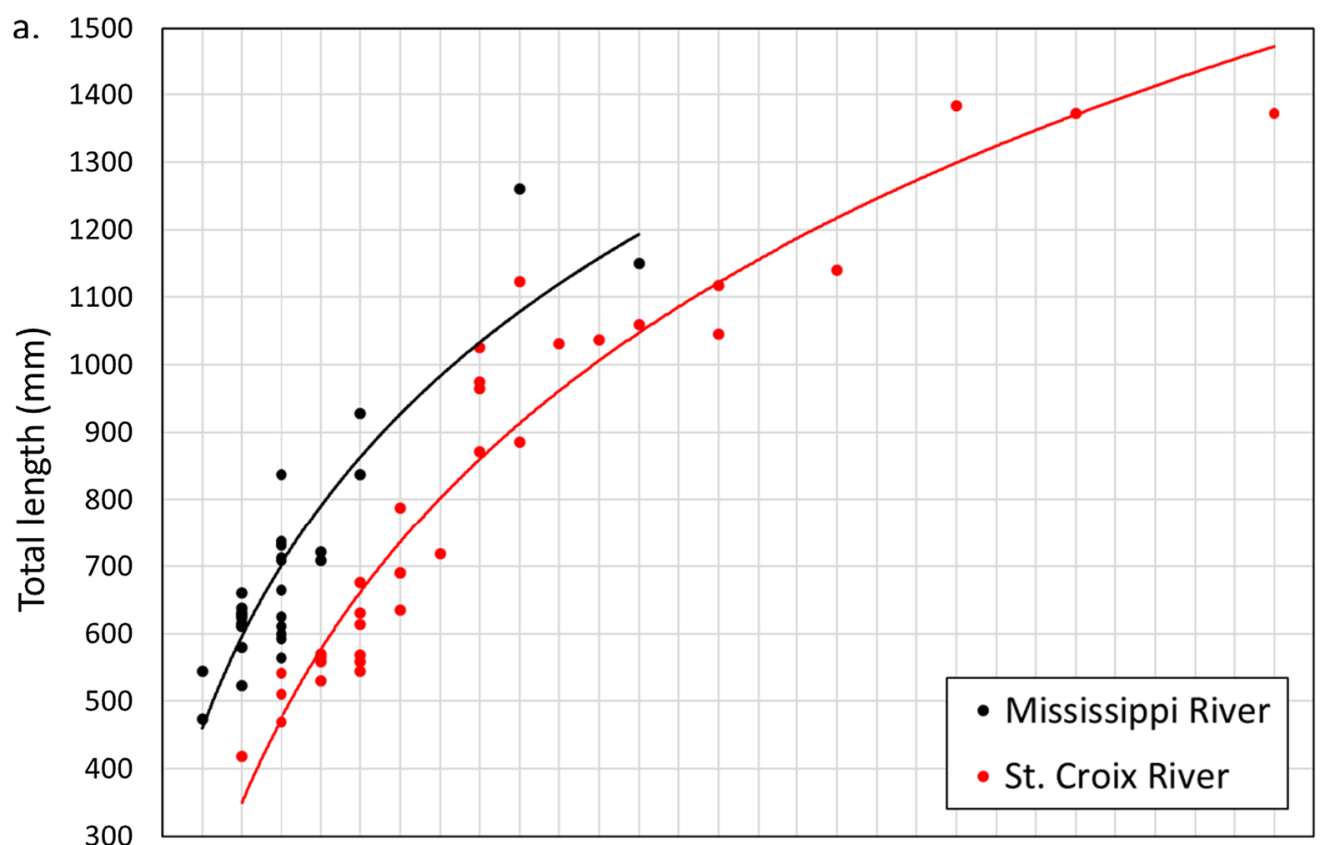

$2 \quad 3 \quad 4 \quad 5 \quad 6 \quad 7 \quad 8 \quad 910111213141516171819202122232425262728293031$

Age (y)

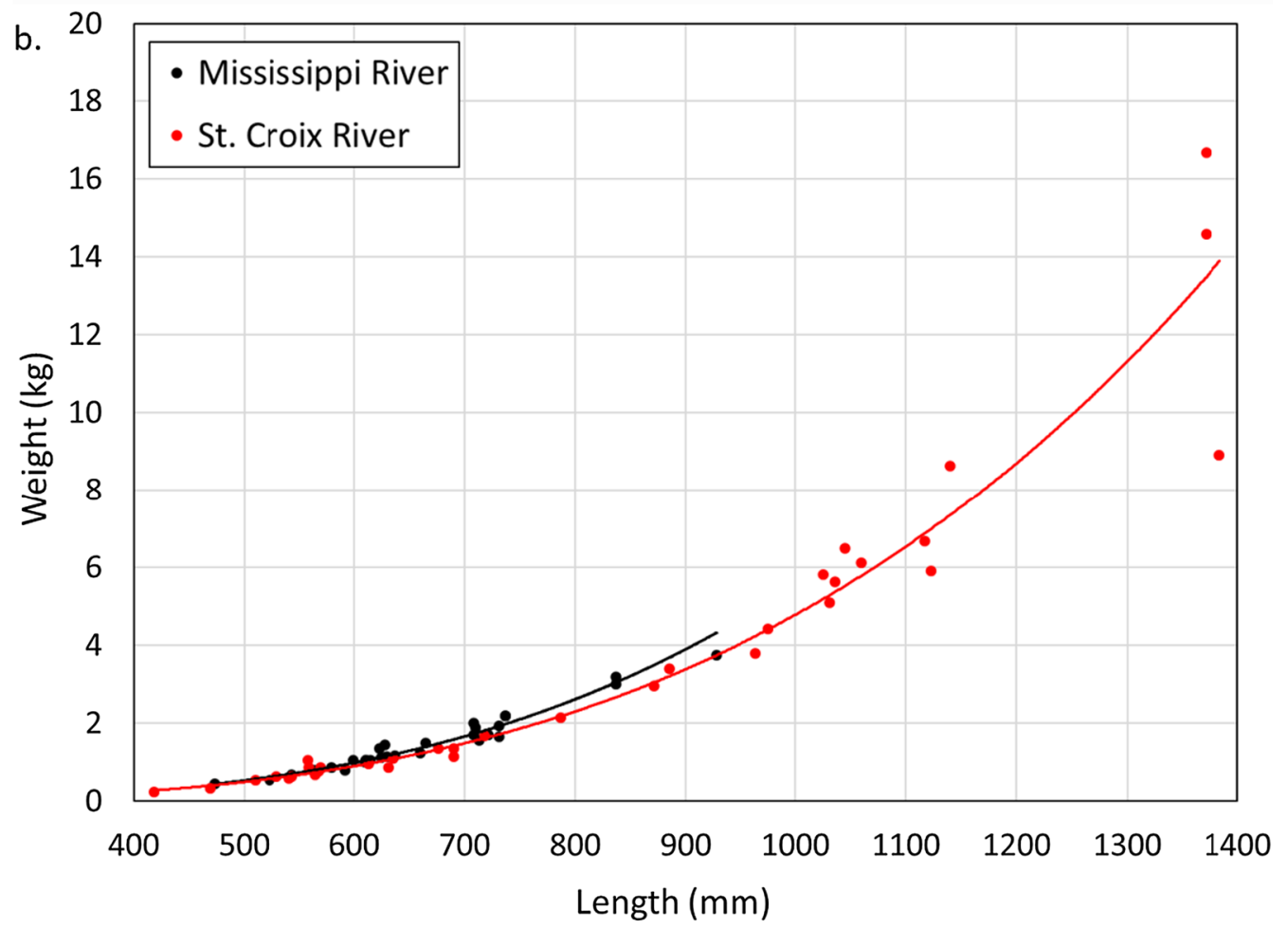

Fig. 4 Age-length (a) and length-weight (b) relations for sample populations (all ages) of lake sturgeon captured in the Mississippi and St. Croix Rivers. a Logarithmic trendlines for each river, and $\mathbf{b}$ power trendlines for each river 


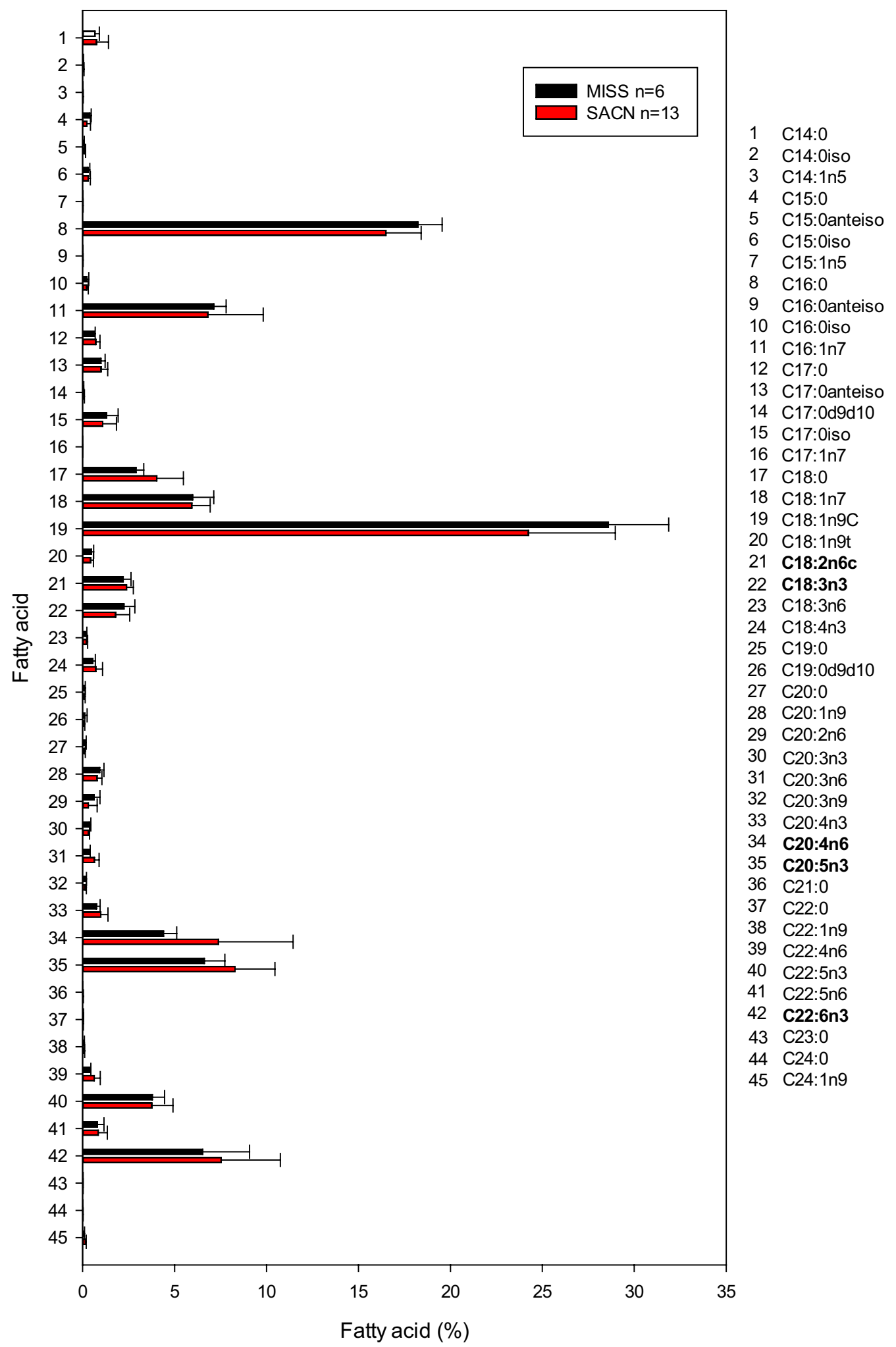

Fig. 5 Mean values and standard deviations of the fatty acids (\%) in tissue (anterior dorsal muscle) samples of lakes sturgeon captured from the Mississippi (MISS) and St. Croix (SACN) Rivers. The essential fatty acids are indicated in bold text and include: LIN (C18:2n6c), ALA (C18:3n3), ARA (C20:4n6), EPA (C20:5n3), and DHA (C22:6n3) 


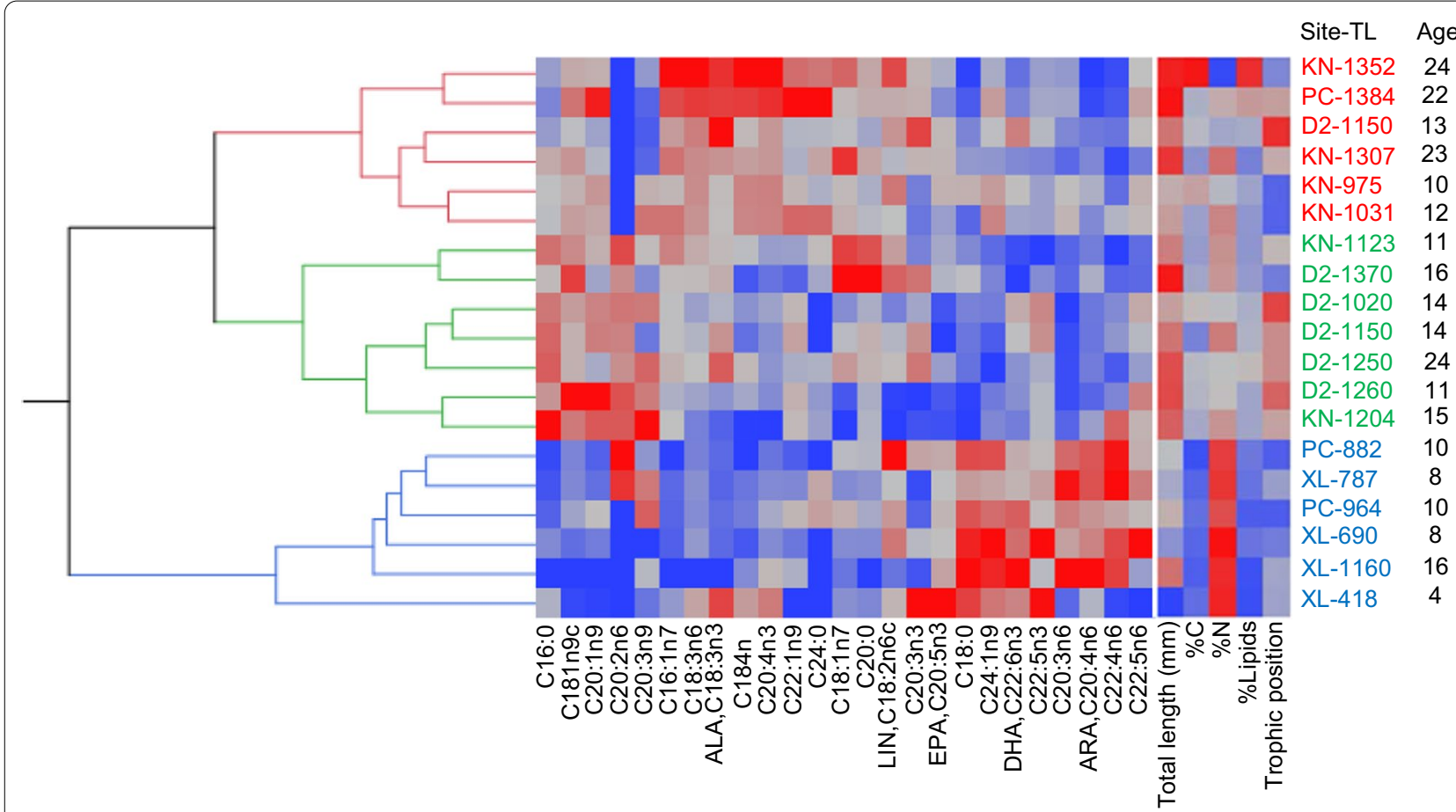

Fig. 6 Cluster analysis showing dendrogram classification and associated heatmap for lake sturgeon based on percent fatty acid (FA mg/g dw/Sum of identified FA mg/g dw*100) in anterior dorsal muscle tissue. Lake sturgeon are identified to the right of the heatmap by capture location and total length $(\mathrm{mm})$, revealing three primary clusters: Kinnickinnic narrows (KN) and near the Xcel Energy Plant (XL) in the St. Croix River, and tailwaters below Lock and Dam 2 (D2) of the Mississippi River. The age (y) of the lake sturgeon is provided for reference. Total length (mm), \% C, \% N, \% lipids, and trophic position are indicator variables provided for reference only and were not included in the cluster analysis. Tiles are colored blue and red based on percent fatty acid, which indicates low and high levels, respectively

C20:3n6 (0.63\%, range 0.38 to $1.1 \%)$; eicosatetraenoic acid, C20:4n3 (0.99\%, range 0.39 to $1.7 \%)$; adrenic acid, C22:4n6 (0.63\%, range 0.30 to $1.1 \%$ ); and docosapentaenoic acid, C22:5n6 (0.85\%, range 0.01 to $1.9 \%)$. Lake sturgeon from the Mississippi River had a higher percentage of eicosadienoic acid, C20:2n6 (0.62\%, range 0 to $0.91 \%)$ and eicosatrienoic acid, C20:3n 3 (0.36\%, range 0.23 to 0.45\%; Fig. 5).

Hierarchical cluster analysis of fatty acids from the lake sturgeon muscle tissue samples (post-dorsal, skin-free) collected from three locations in the St. Croix River and one location within the Mississippi River (Fig. 1) revealed three distinct clusters: fish captured near Lock and Dam 2 (D2) of the Mississippi River, fish captured near Kinnickinnic narrows (KN), and fish captured near the Xcel Energy Plant (XL), with fish captured at Prescott, Wisconsin (PC, $n=3$ ) distributed among the other clusters (Fig. 6). The lake sturgeon captured near the Xcel Energy Plant had a higher percentage of the essential fatty acids ARA (C20:4n6), EPA (C20:5n3), and DHA (C22:6n3) compared to the other two clusters. Lake sturgeon captured near the Xcel Energy Plant area also had a lower percentage of ALA (C18:3n3) compared to the
Kinnickinnic and Mississippi River groups. Lake sturgeon captured near the Xcel Energy Plant were primarily classified as juveniles based on their total length and estimated age (Fig. 6).

\section{Stable isotopes}

The biplot of $\delta^{15} \mathrm{~N}$ and $\delta^{13} \mathrm{C}$ for lake sturgeon showed primarily three distinct groups (Fig. 7). The first distinct group had the highest $\delta^{15} \mathrm{~N}$ values $\left(\delta^{15} \mathrm{~N}=16.6 \%\right.$, range 16.0 to $17.5 \%$ ) and was primarily comprised of lake sturgeon captured near Lock and Dam 2 of the Mississippi River; however, this group also included three lake sturgeon from Kinnickinnic narrows $\left(\delta^{15} \mathrm{~N}=16.2 \%\right.$, range 16.0 to $16.4 \%$ ) and one lake sturgeon from Prescott $\left(\delta^{15} \mathrm{~N}=16.4 \%\right)$. The second distinct group included the other three lake sturgeon captured from Kinnickinnic narrows and one from Prescott, WI. The third distinct group included three of the four lake sturgeon captured near the Xcel Energy Plant. The lake sturgeon with a total length of $690 \mathrm{~mm}$ was the most depleted in both carbon $\left(\delta^{13} \mathrm{C}=-34.1 \%\right)$ and nitrogen $\left(\delta^{15} \mathrm{~N}=11.0 \%\right)$ values relative to other sampled lake sturgeon (Fig. 7). 


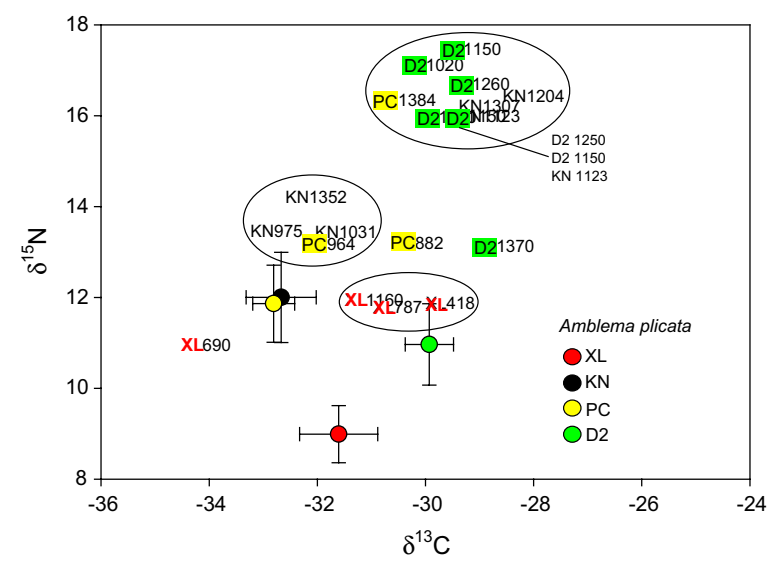

Fig. 7 Isotopic composition $\left(\delta^{15} \mathrm{~N}\right.$ and $\left.\delta^{13} \mathrm{C}\right)$ of lake sturgeon captured in the Mississippi River near lock and dam 2 (D2) and in the St. Croix River near the Xcel Energy Plant (XL), Kinnickinnic narrows $(\mathrm{KN})$, and near Prescott, Wisconsin, USA (PC). Mean values $\pm 95 \%$ confidence intervals of $\delta^{15} \mathrm{~N}(\%)$ and $\delta^{13} \mathrm{C}(\%)$ in Amblema plicata (circle symbols), which served as the baseline primary consumer used to estimate the trophic position of the lake sturgeon. Values are not adjusted for trophic shift

The estimated trophic position of lake sturgeon, controlling for site-specific baseline unionid $\delta^{15} \mathrm{~N}$ variation, ranged from 2.7 to 4.2 and varied by location. Lake sturgeon captured in the Mississippi River had an estimated mean trophic position of 3.7. However, one of the lake sturgeon from the Mississippi River $(\mathrm{TL}=1370 \mathrm{~mm}$, P3-03 in Table 1) had an estimated trophic position of 2.7. Comparatively, two of the six lake sturgeon captured in the lower St. Croix River, near Kinnickinnic narrows, had an estimated trophic position of 3.4, while the other four lake sturgeon captured near Kinnickinnic narrows had an estimated mean trophic position of 2.8. The lake sturgeon captured near the Xcel Energy Plant (3 of 4 fish; $\mathrm{TL}=418,787$, and $1160 \mathrm{~mm}$ ) had an estimated mean trophic position of 3.0 and the fourth $(\mathrm{TL}=690 \mathrm{~mm})$ had an estimated trophic position of 2.7. Two smaller fish ( $\mathrm{TL}=882$ and $964 \mathrm{~mm}$ ) captured near Prescott had an estimated trophic position of 2.4 , and the largest fish $(\mathrm{TL}=1384 \mathrm{~mm})$ had an estimated trophic position of 3.5. Stable isotope data from this study are published in Zigler et al. (2021).

\section{Water analyses}

Water samples collected seasonally (spring, summer, and fall of 2015) from three sites in the Mississippi River (USGS stations 05288930, 05331580, and 05344980, U.S. Geological Survey 2016) and three sites in the St. Croix River (USGS stations 05340540, 05341550, and 05344490, U.S. Geological Survey 2016) that spanned the range capture locations of lake sturgeon sampled for tissue analysis in this study were analyzed for $\mathrm{Sr}$ :Ca values (in $\mu$ moles of $\mathrm{Sr}$ per mole of $\mathrm{Ca}, \mu \mathrm{mol} / \mathrm{mol}$ ) according to USGS protocols described in Ziegeweid et al. (2018). Measured Sr:Ca values were higher in the Mississippi River $($ mean $=1140 \mu \mathrm{mol} / \mathrm{mol}$, range $=849-1430 \mu \mathrm{mol} /$ mol, $n=9$ ) than in the St. Croix River (mean $=836 \mu \mathrm{mol} /$ mol, range 701-941 $\mu \mathrm{mol} / \mathrm{mol}, n=9$ ). The observed ratio of mean $\mathrm{Sr}: \mathrm{Ca}$ values in water from the Mississippi and St. Croix Rivers in this study $(1140 \mu \mathrm{mol} / \mathrm{mol}$ divided by $836 \mu \mathrm{mol} / \mathrm{mol}$ ) was 1.36 . Measured concentrations of $\mathrm{Sr}$ $(\mu \mathrm{g} / \mathrm{L})$ and $\mathrm{Ca}(\mathrm{mg} / \mathrm{L})$ are published in the USGS National Water Information System (NWIS, U.S. Geological Survey 2016$)$, and $\mathrm{Sr}: \mathrm{Ca}$ values $(\mu \mathrm{mol} / \mathrm{mol})$ are summarized by sampling location in Appendix Table 2-1 of Ziegeweid et al. (2018).

\section{Fin ray trace elements}

Sensitivity of ${ }^{46} \mathrm{Ca}$ was above zero for all calibrations, and values of ${ }^{46} \mathrm{Ca}$ were rounded to zero (Additional file 2). Values of $\mathrm{Sr}: \mathrm{Ca}$ in analysis group 1 (November 2015) were standardized to group 2 (March 2016). The correction factor of $0.72(n=8$, Table 2$)$ applied to analyzed fin rays in group 1 (November 2015) was based on ratios of $\mathrm{Sr}$ :Ca values for fin ray portions analyzed in both sample groups. Original paired groups 1 and 2 data were significantly linearly related $(F=15.84, d f=7, p<0.01)$. One fin ray (MNLKS20) was excluded from the original dataset (Table 2) as an outlier when computing the mean ratio of $\mathrm{Sr}: \mathrm{Ca}$ because the relative percent difference between the March 2016 and corrected November 2015 values was about five times larger than the relative percent difference between the March 2016 and uncorrected November 2015 values (Table 2). Furthermore, inclusion of the fin ray outlier did not change the significance of the relation $(p<0.05)$ and only modestly affected the correction factor $(0.75)$, but the coefficient of determination $\left(R^{2}\right)$ increased from 0.439 to 0.694 when the outlier was excluded (Fig. 8). Corrected and uncorrected Sr:Ca data from laser ablation analyses completed in November 2015 and March 2016 are published in Zigler et al. (2021) and included in Additional file 3.

Results of the one-way ANOVA indicated significant differences in mean $\mathrm{Sr}$ :Ca values among the four combinations of rivers (Mississippi and St. Croix Rivers) and fin ray locations (capture and natal, $d f=3, p<0.001$ ). Tukey's HSD tests demonstrated that natal (mean $=256 \mu \mathrm{mol} /$ mol; $d f=30 ; 95 \%$ CI 246, 266) and capture location (mean $=278 \mu \mathrm{mol} / \mathrm{mol} ; d f=29 ; 95 \%$ CI 264, 293) Sr:Ca values were not significantly different for lake sturgeon captured in the Mississippi River $(p=0.12)$. Furthermore, natal $($ mean $=206 \mu \mathrm{mol} / \mathrm{mol} ; d f=29 ; 95 \%$ CI 188, 224) and capture location (mean $=208 \mu \mathrm{mol} / \mathrm{mol} ; d f=21$; 95\% CI 191, 225) Sr:Ca values were not significantly 
Table 2 Comparisons of sturgeon fin ray laser ablation data collected in November 2015 and March 2016

\begin{tabular}{|c|c|c|c|c|c|c|c|}
\hline Fish ID & Fin ray portion & $\begin{array}{l}\text { November } \\
\mathrm{Sr}: \mathrm{Ca}^{\mathrm{a}}(\mu \mathrm{mol} / \\
\mathrm{mol})\end{array}$ & $\begin{array}{l}\text { March Sr:Ca } \\
(\mu \mathrm{mol} / \mathrm{mol})\end{array}$ & $\begin{array}{l}\text { Relative } \\
\text { percent } \\
\text { difference (\%) }\end{array}$ & $\begin{array}{l}\text { March Sr:Ca/ } \\
\text { November } \\
\text { Sr:Ca }\end{array}$ & $\begin{array}{l}\begin{array}{l}\text { Corrected } \\
\text { November Sr:Ca } \\
(\mu \mathrm{mol} / \mathrm{mol})\end{array} \\
\end{array}$ & $\begin{array}{l}\text { Corrected relative } \\
\text { percent difference } \\
(\%)\end{array}$ \\
\hline MNLKS20 ${ }^{b}$ & Core & 294 & 279 & 5.2 & 0.95 & 212 & 27.4 \\
\hline MNLKSO9 & Core & 299 & 208 & 35.9 & 0.70 & 215 & 3.4 \\
\hline MNLKS11 & Core & 277 & 238 & 15.1 & 0.86 & 199 & 17.6 \\
\hline MNLKS15 & Core & 268 & 195 & 31.5 & 0.73 & 193 & 1.1 \\
\hline MNLKS16 & Core & 273 & 201 & 30.4 & 0.74 & 197 & 2.2 \\
\hline MNLKS25 & Core & 335 & 220 & 41.4 & 0.66 & 241 & 9.2 \\
\hline MNLKS25 & Edge & 368 & 281 & 26.8 & 0.76 & 265 & 5.9 \\
\hline MNLKS27 & Core & 292 & 213 & 31.3 & 0.73 & 210 & 1.3 \\
\hline \multirow[t]{4}{*}{ MNLKS27 } & Edge & 299 & 192 & 43.6 & 0.64 & 215 & 11.4 \\
\hline & Average & 311 & 225 & 32.3 & 0.72 & 224 & 6.0 \\
\hline & Standard Deviation & 44 & 33 & 8.4 & 0.06 & 32 & 5.7 \\
\hline & Standard Error & 15 & 11 & 2.8 & 0.02 & 11 & 1.9 \\
\hline
\end{tabular}

\footnotetext{
a Strontium (Sr) to calcium (Ca) ratio
}

${ }^{\mathrm{b}}$ This lake sturgeon was excluded as an outlier from calculation of mean ratio used to correct November data based on comparisons of linear regression analysis and relative percent differences among March data and both corrected and uncorrected November data

This value (bold) represents the multiplicative correction applied to Sr:Ca values for fin rays analyzed in November 2015 (group 1)

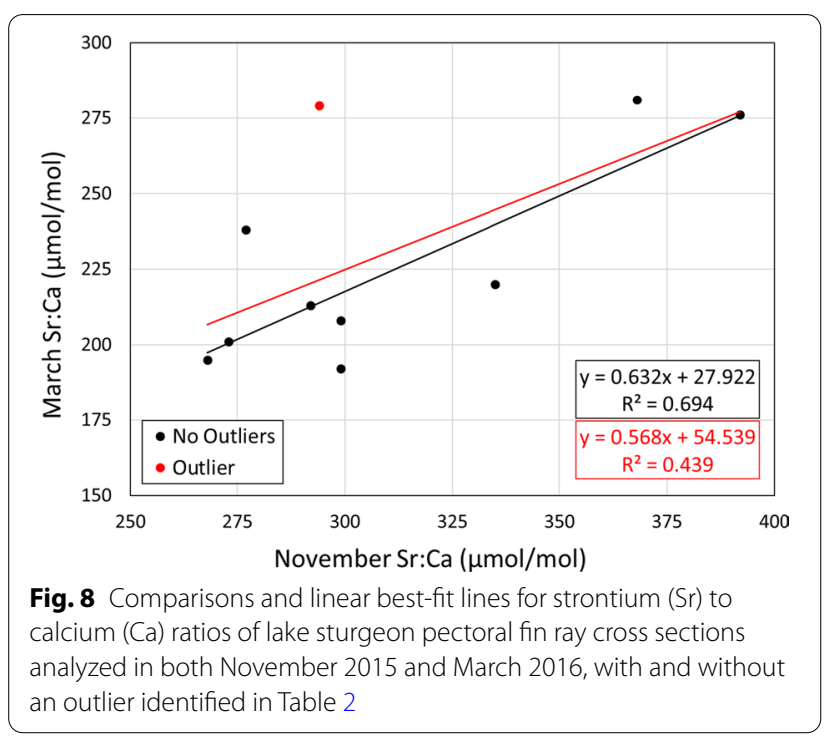

different for lake sturgeon captured in the St. Croix River $(p=0.997)$. However, mean $\mathrm{Sr}$ :Ca values were significantly different for both between-river comparisons $(p<0.001)$. Distributions of Sr:Ca values for the four combinations of rivers and fin ray locations are illustrated using boxplots (Fig. 9, Additional file 4). The observed ratio of mean $\mathrm{Sr}$ :Ca values associated with capture locations from lake sturgeon captured in the Mississippi and St. Croix Rivers in this study $(278 \mu \mathrm{mol} / \mathrm{mol}$ divided by $208 \mu \mathrm{mol} / \mathrm{mol}$ ) was 1.34 .

General migratory patterns of individual lake sturgeon were examined graphically using the full "core to

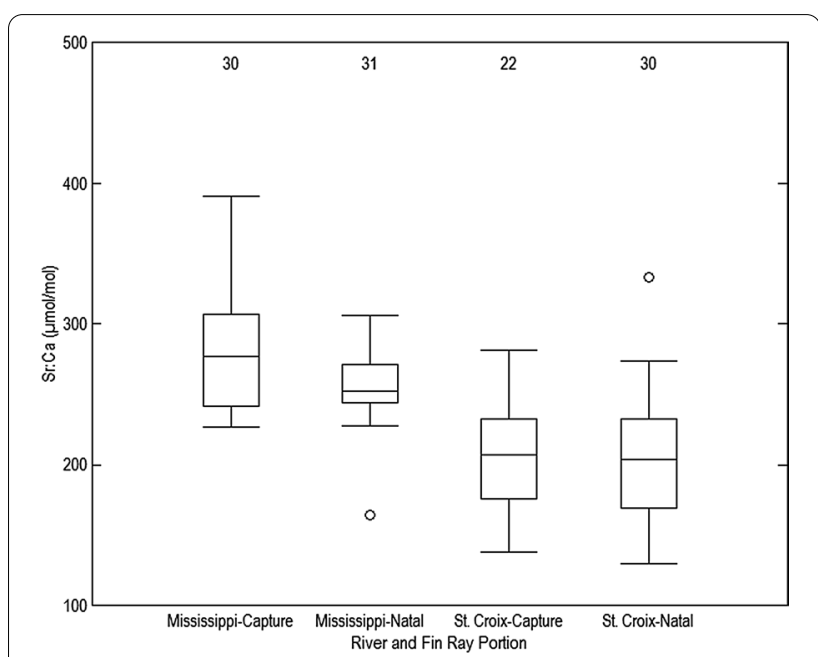

Fig. 9 Boxplots illustrating the distributions of strontium (Sr) to calcium (Ca) ratios measured in natal and capture location portions of pectoral fin rays from lake sturgeon captured in the Mississippi and St. Croix Rivers. Numerals above the boxes represent the number of lake sturgeon sampled for each combination of river and fin ray portion. Boxes represent interquartile ranges, with center lines in representing median values and the upper and lower ends of the boxes representing the 75 th and 25 th percentiles, respectively. Whiskers represent values within 1.5 times of the interquartile range, either above the 75th percentile or below the 25th percentile. Data points plotted as open circles represent values within 3 times the interquartile range

edge" laser ablation transect data obtained for fin rays analyzed in group 1 (November 2015, $n=49$, Zigler et al. 2021). Wide variations in Sr:Ca patterns were 


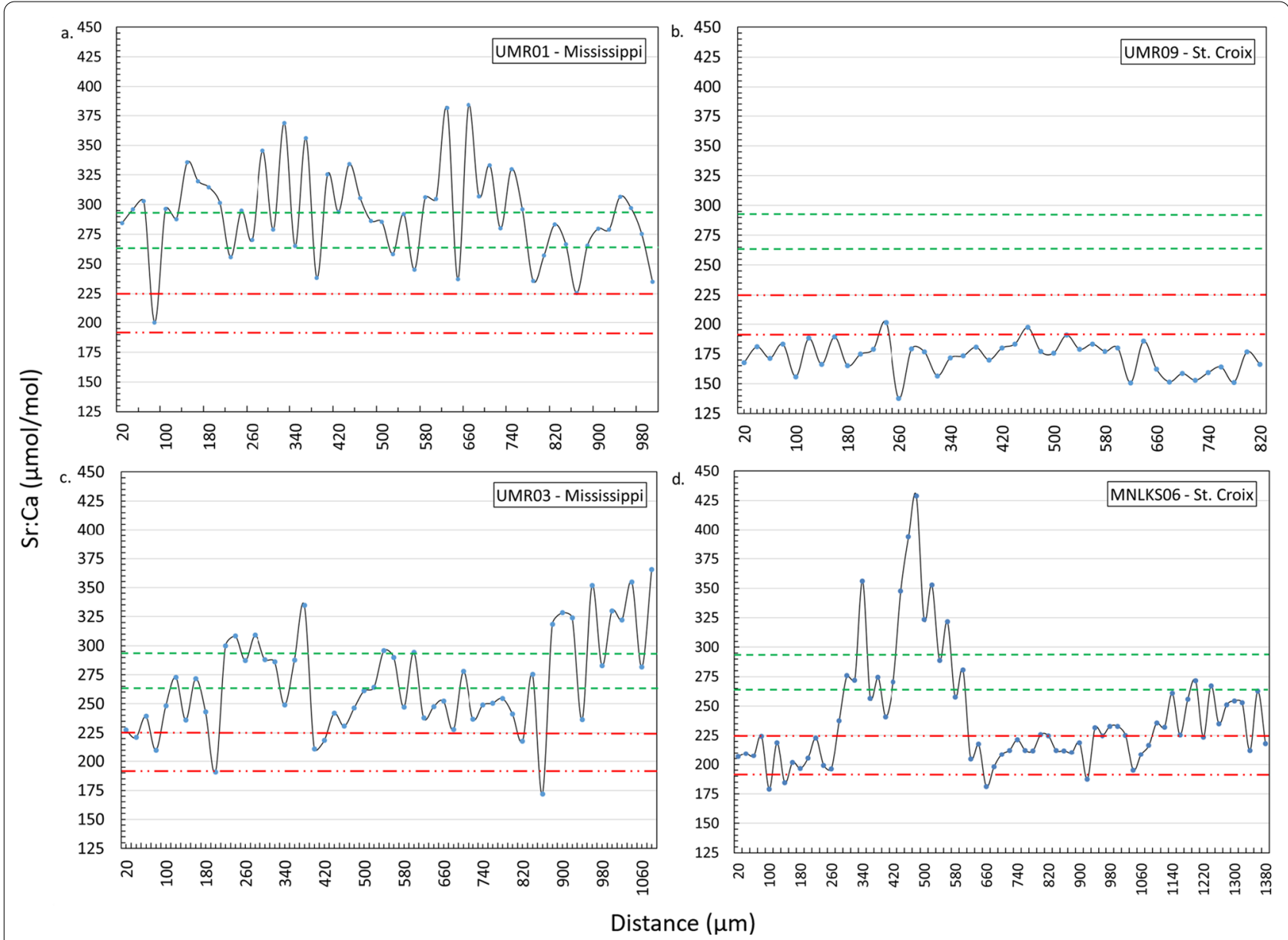

Fig. 10 Pectoral fin ray transect data for individual lake sturgeon from the Mississippi (a, c) and St. Croix (b, d) Rivers that demonstrate low (a, b) and high (c, d) migratory variability throughout the life of the fish. Green dashed lines and red dashed and dotted lines represent $95 \%$ confidence intervals for "edge" data that represent capture location from sturgeon captured in the Mississippi and St. Croix Rivers, respectively. Fish identifiers included in each figure panel (UMR01, UMR09, UMR03, MNLKS06) correspond to fish identifiers used in laser ablation data presented in Additional file 3 and Zigler et al. (2021)

observed among fin rays (Additional file 3), indicating that migratory patterns varied considerably among individual lake sturgeon. For example, some lake sturgeon captured in both the Mississippi and St. Croix Rivers had low variability $\mathrm{Sr}$ :Ca ratios across their life history (Fig. 10a and b), which may indicate these fish remained in their natal rivers throughout their life. In contrast, other lake sturgeon (Fig. 10c and d) had high variability in $\mathrm{Sr}$ :Ca ratios including values that suggest these sturgeons may have migrated between river systems with noticeably different $\mathrm{Sr}$ :Ca water signatures (Ziegeweid et al. 2018). In general, lake sturgeon captured from the Mississippi River showed more variability in fin ray $\mathrm{Sr}$ :Ca values than those captured in the St. Croix River (Additional file 3, Zigler et al. 2021).

\section{Discussion}

This study provides baseline lipid, fatty acid, and trophic position data for lake sturgeon prior to the establishment of invasive carp populations within the MISS and SACN NPS units. Relatively little is known of the fatty acid profiles of wild Acipenser spp., and even less is known about lake sturgeon fatty acid profiles (Williams et al. 2014, 2017). A comparison of lipid profiles from lake sturgeon, which evolved 250 million years ago, to more derived fishes (i.e., teleost) may not be informative or appropriate. Although a number of aquaculture diet studies have been conducted using various lipid, protein, and micronutrient combinations, the fatty acid profiles in muscle tissue of lake sturgeon in relation to their overall physical health or metabolic performance have not been measured (Hung 2017). Therefore, we are unable to 
make direct comparisons to these diet studies; however, our data can serve as a reference point in time for future tissue condition comparisons of lake sturgeon should a large perturbation to the system occur, such as a widespread establishment of invasive carps or installation of barriers to fish migration at the mouth of the St. Croix River (Ad Hoc Asian Carp Task Force 2011).

Increased concentrations of fatty acids DHA $(\mathrm{C} 22: 6 \mathrm{n} 3)$ and EPA (C20:5n3) have been associated with improved diet and metabolic condition; however, absolute benchmarks have not been established in the literature (Tocher 2003). Therefore, concentrations of DHA and EPA observed in this study were compared to published concentrations for lake sturgeon from the Menominee River (Williams et al. 2014; $n=3$, mean total length $=1292 \mathrm{~mm}$ ) and Lake Michigan (Williams et al. 2017; $n=6$, mean total length $=1440 \mathrm{~mm} \pm 81.3 \mathrm{SE}$ ). The average DHA (C22:6n3) concentration observed in this study ( $5.59 \mathrm{mg} / \mathrm{g} \mathrm{dw} \pm 0.69 \mathrm{SE}$ ) was $12 \%$ lower than the average DHA concentration observed in fish from the Menominee River $(6.38 \mathrm{mg} / \mathrm{g} \mathrm{dw} \pm 1.47 \mathrm{SE}$, based on an assumed tissue water content of $77.75 \%$; Williams et al. 2014) and $41 \%$ lower than the average DHA concentration observed in fish from Lake Michigan $(9.47 \mathrm{mg} / \mathrm{g}$ $\mathrm{dw} \pm 2.0 \mathrm{SE}$, based on an assumed tissue water content of 77.75\%; Williams et al. 2017). In contrast, the average EPA (C20:5n3) concentration observed in this study $(6.65 \mathrm{mg} / \mathrm{g} \mathrm{dw} \pm 0.86 \mathrm{SE})$ was $15 \%$ higher than the average EPA concentration observed in fish from Lake Michigan (5.58 mg/g dw $\pm 1.58 \mathrm{SE}$; Williams et al. 2017) and three times higher than the average EPA concentration observed in fish from the Menominee River $(2.05 \mathrm{mg} / \mathrm{g}$ $\mathrm{dw} \pm 1.90$ SE; Williams et al. 2014).

Ratios of DHA:EPA have been shown to correlate with growth rates, with DHA:EPA ratios of 2:1 (range 1:1 to 8:1 or higher) resulting in the highest growth in teleost fishes (Arts et al. 2009). Therefore, ratios of DHA:EPA obtained from lake sturgeon collected in this study were compared to DHA:EPA ratios of previous studies in the Menominee River (Williams et al. 2014) and Lake Michigan (Williams et al. 2017) to further compare the growth of lake sturgeon among different populations. Lake sturgeon collected from the Menominee River had a DHA:EPA ratio of 3.1 (Williams et al. 2014). Lake sturgeon collected from Lake Michigan had a DHA:EPA ratio of 1.7 (Williams et al. 2017). In contrast, lake sturgeon collected from the St. Croix and Mississippi Rivers in this study had a DHA:EPA ratio of 0.85. Results of DHA:EPA ratio comparisons indicate that lake sturgeon in the St. Croix and Mississippi Rivers grow more slowly than lake sturgeon in Lake Michigan and the Menominee River. These results also support the lower condition factors and length-weight relations noted in previous studies of lake sturgeon from the St. Croix River (Engel 1990; Ramsell 2010), indicating that lake sturgeon populations in the St. Croix and Mississippi Rivers could be particularly susceptible to declines caused by changes in food web dynamics related to establishment of reproducing populations of invasive carps.

Essential fatty acid concentrations from the three hierarchical clusters identified in our study (Lock and Dam 2 of Mississippi River, Kinnickinnic narrows of the St. Croix River, and near the Xcel Energy Plant on the St. Croix River, Zigler et al. 2021) were compared to data published on other wild-caught lake sturgeon from the Menominee River. Lake sturgeon from the St. Croix and Mississippi Rivers had LIN (C18:2n6c) concentrations that were 6 to 22 times higher, ALA (C18:3n3) concentrations that were 1.7 to 11 times higher, and EPA (C20:5n3) concentrations that were 1.6 to 4.7 times higher compared to lake sturgeon from the Menominee River. Concentrations of DHA (C22:6n3) for lake sturgeon from the St. Croix and Mississippi Rivers ranged from 0.6 to 1.2 times the mean DHA concentration adult lake sturgeon from the Menominee River (Fig. 11; Williams et al. 2014). In contrast, concentrations of ARA (C20:4n6) in lake sturgeon tissue from our study were similar $( \pm 1 \mathrm{SE})$ to those from the Menominee River (Fig. 11, Williams et al. 2014). Generally, lake sturgeon captured near the Xcel Energy Plant had lower fatty acid concentrations (mean FA $\mathrm{mg} / \mathrm{g} \mathrm{dw}$ ) than the other two clusters (Lock and Dam 2 of Mississippi River and Kinnickinnic narrows, Fig. 11), and three of the four lake sturgeon captured at the Xcel Energy Plant were juveniles.

We have demonstrated that the lake sturgeon from the St. Croix and Mississippi Rivers appear to have similar or higher concentrations of these important EFAs (LIN (C18:2n6c), ALA (C18:3n3), ARA (C20:4n6), EPA (C20:5n3) except for the lower DHA (C22:6n3) concentration in the Xcel Energy cluster, Fig. 11) compared to other wild-caught lake sturgeon. Higher concentrations of DHA (C22:6n3) have been liked to higher growth rates in several marine species and some freshwater fish species (Arts et al. 2009). In aquatic food webs, DHA (C22:6n3) is a fatty acid marker for dinoflagellates, which also produce other EFAs that are considered beneficial for health or enhanced growth (Ahlgren et al. 1997). However, threshold concentrations have not been established for these EFAs to determine if the observed concentrations are insufficient or limiting for growth or reproduction (Tocher 2003).

Interestingly, the lake sturgeon captured near the Xcel Energy Plant were primarily juveniles, and the dorsal muscle tissue of these fish contained a higher proportion of two essential fatty acids, DHA (C22:6n3) and ARA (C20:4n6), relative to their total fatty acid composition 


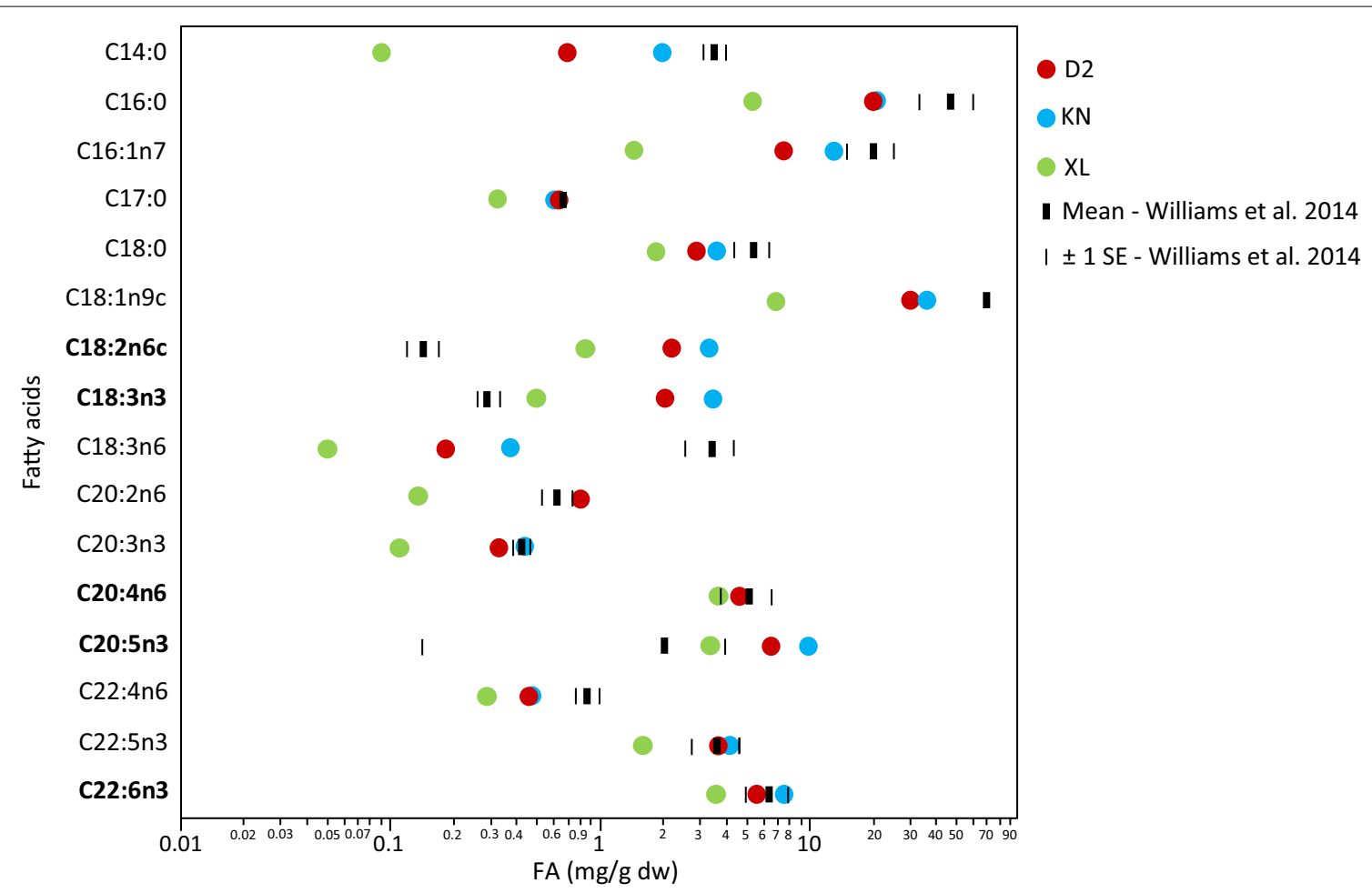

Fig. 11 Mean fatty acid concentration (FA mg/g dw) in anterior dorsal muscle tissue of lake sturgeon $(n=19)$ clustered into three primary groups: tailwaters below Lock and Dam 2 (D2, red circle) of the Mississippi River, Kinnickinnic narrows (KN, blue circle) and near the Xcel Energy Plant (XL, green circle), both in the St. Croix River. The fatty acid concentration (converted to $\mathrm{mg} / \mathrm{g} \mathrm{dw}$ ) of lake sturgeon (fillets, $n=3$ ) sampled from the Menominee River are provided for comparison (black squares \pm 1 SE, Williams et al. 2014). The essential fatty acids are indicated in bold text and include: LIN (C18:2n6c), ALA (C18:3n3), ARA (C20:4n6), EPA (C20:5n3), and DHA (C22:6n3). All fatty acid data presented in this figure are published in Zigler et al. (2021)

(Fig. 6, Zigler et al. 2021). These juvenile lake sturgeons also had the lowest percent lipids of all the lake sturgeon sampled in this study. Although we did not attempt to separate storage (neutral) lipids from structural (phospholipids) lipids in our analysis, the general pattern represents a lean fish condition, such that their tissue fatty acid composition is likely dominated by structural or membrane lipids compared to storage lipids (Adams 1999). These juvenile lake sturgeons also contained a higher proportion of nitrogen (\%) and lower proportion of carbon (\%) content in their tissues compared to the lake sturgeon capture from other locations. The higher nitrogen (\%) and lower carbon (\%) is reflective of reduced lipids in fat storage of younger fish; storage lipids and associated triacylglycerols are carbon rich (Tocher 2003).

Our stable isotope data indicate lake sturgeon were feeding at different trophic positions across our sites. For example, lake sturgeon captured in the Mississippi River were feeding at a higher trophic level (3.7) compared to those in the St. Croix River (mean 2.9, trophic range, 2.4 to 3.5 , after controlling for site-specific baseline unionid $\delta^{15} \mathrm{~N}$ variation). The trophic position increased in 12 of the 19 lake sturgeon moving downstream in the St. Croix River into the Mississippi River. However, three lake sturgeon captured near Kinnickinnic narrows (mean trophic position 3.4) and one from Prescott (trophic position 3.5) appeared to also be feeding at a higher trophic level. The trophic position of lake sturgeon from the Mississippi River was not as high as the estimated trophic position of 4.8 (controlled for baseline ${ }^{15} \mathrm{~N}$ variation) for lake sturgeon from the Niagara River (Bruestle et al. 2019). However, this increased trophic position was likely caused by lake sturgeon targeting and feeding on invasive round gobies (Neogobius melanostomus, $>98 \%$ of diet based on a model developed using the $\mathrm{R}$ package 'siar') in the Lake Ontario system (Bruestle et al. 2019). A similarly high trophic position (4.6) was estimated for adult lake sturgeon (>1000 mm TL) from the Rainy River system in Ontario, Canada, and was attributed to consumption of organic material derived from fish (e.g., fish eggs, larval die-offs or adult fish winter die-offs; Smith et al. 2016). In contrast, lake sturgeon in Lake Winnebago, Wisconsin, had a mean trophic position of 3.0 (Stelzer et al. 2008), which is similar to the mean trophic position of 
lake sturgeon in this study. Stelzer et al. (2008) indicated that the trophic position of lake sturgeon in Lake Winnebago may be related to the digestion of gizzard shad (Dorosoma cepedianum) after winter die-off events, and lake sturgeon in the SACN and MISS may have similar food choices. Anecdotal reports indicate that fishers use gizzard shad as bait when targeting lake sturgeon in sport fishing.

The stable isotopic signatures of one of the 19 lake sturgeon captured in this study support the fin ray ablation data indicating that these two populations of lake sturgeon within the St. Croix and Mississippi Rivers do appear to be linked by movement of individual fish. For example, the stable isotopic signature $\left(13.1 \%\right.$ o for $\delta^{15} \mathrm{~N}$, $-28.5 \%$ for $\delta^{13} \mathrm{C}$ ) of an adult lake sturgeon (Fig. 10c, lake sturgeon No. UMR03, $1370 \mathrm{~mm}$ TL) captured in the Mississippi River indicates that this fish is either feeding at a much lower trophic level compared to others captured at this location or it is a fish with high mobility between the two river systems. The fatty acid composition of this lake sturgeon is similar to the others captured in the Mississippi River, indicating that the fish is eating a similar food source. Therefore, the data appear to support the high mobility of this fish between the Mississippi and St. Croix Rivers.

Water and fin rays collected from the Mississippi and St. Croix Rivers appear to have distinct $\mathrm{Sr}$ :Ca signatures that could be used to track natal origins and migratory histories of lake sturgeon. Analyses of signatures in water summarized in Ziegeweid et al. (2018) showed that $\mathrm{Sr}: \mathrm{Ca}$ ratios in the Mississippi River, downstream from the confluence with the Minnesota River, were higher (849$1430 \mu \mathrm{mol} / \mathrm{mol}$ ) than the St. Croix River (701-941 $\mu \mathrm{mol} /$ mol) across seasons and flow conditions. The high values within the Mississippi River (generally $>1100 \mu \mathrm{mol} /$ mol) may persist downstream to at least Navigation Pool 19 of the Mississippi River (Whitledge et al. 2019). Additional water chemistry samples collected over a range of seasons and flow conditions would help refine chemical signatures.

Similar ratios of mean $\mathrm{Sr}$ :Ca values in Mississippi and St. Croix River water (1.36) and capture location portions of lake sturgeon fin ray cross sections (1.34) indicate that differences in $\mathrm{Sr}$ :Ca values near the margin of lake sturgeon pectoral fin ray cross sections that represent the most recent growth generally corresponded to differences in the $\mathrm{Sr}: \mathrm{Ca}$ signatures in waters of the St. Croix and Mississippi Rivers where lake sturgeons were captured. For both rivers, Sr:Ca values measured in water were about four times larger than $\mathrm{Sr}$ :Ca values measured in fin ray cross sections. Some lake sturgeons in our study could have moved into the waters where they were captured too recently to fully incorporate the trace element composition of water near the capture site. However, based on an estimated age at sexual maturity of 15 years (Peterson et al. 2007), 83\% of the sampled lake sturgeon in our study were juveniles that are less likely to travel outside of their natal river (Peterson et al. 2007). The observed proportion of juvenile fish reduces some concerns about migration, but controlled exposures in known water chemistries would be needed to verify relations between $\mathrm{Sr}$ :Ca values in water and lake sturgeon pectoral fin rays (Phelps et al. 2012). Controlled exposures could also be used to identify thresholds for classifying movements between rivers based on measured $\mathrm{Sr}$ :Ca values in fin ray cross sections (Phelps et al. 2012).

Measured $\mathrm{Sr}: \mathrm{Ca}$ in fin rays indicate that there is substantial variation in movement patterns among individual lake sturgeon across their lifetimes. However, the results of the ANOVA and Tukey's HSD tests indicate that most sturgeon sampled in this study were born in locations with similar Sr:Ca values to the locations from which they were captured. Some lake sturgeon appeared to periodically move between the Mississippi and St. Croix Rivers, but most lake sturgeon were captured in water with a $\mathrm{Sr}: \mathrm{Ca}$ signature that corresponded to their natal waters. This indicates some separation between populations of lake sturgeon in the two rivers. However, most of the fin rays analyzed in this exploratory study came from juvenile fish. Therefore, our results may be different if more adult year classes were represented because lake sturgeon exhibit different migratory behaviors as juveniles and adults, mostly related to changes in foraging opportunities with growth and upstream migrations for adults to spawn in their rivers of natal origin (Peterson et al. 2007). Conclusions presented in this study are based on relatively small sample sizes, especially given the high variability associated with fin ray laser ablation data (Wells et al. 2003; Crook and Gillanders 2006; Elsdon and Gillanders 2006; Elsdon et al. 2008; Humston et al. 2010; Phelps et al. 2012). Therefore, collection and analyses of more fin rays representing a broader range of year classes could help to further identify movement and habitat use patterns of lake sturgeon in the St. Croix and Mississippi Rivers.

Limitations of laser ablation analyses warrant consideration when interpreting and applying results of this study. Laser ablation transects used to measure $\mathrm{Sr}: \mathrm{Ca}$ in fin ray cross sections analyzed in November 2015 were run continuously from the core to edge, but March 2016 analyses used separate, smaller transects to target core and edge portions of fin ray cross sections representing natal and capture locations, respectively. In addition, the laser ablation analyst selected fin ray transect locations that represented the shortest distance between the fin ray core and edge (Fig. 2). In 
future studies using laser ablation, selecting transects that measure the longest parts of the fin ray cross sections might help to distinguish further within-year patterns and timing of lake sturgeon migrations.

A multiplicative correction was developed and applied to increase comparability between laser ablation analysis periods and remove systematic bias that could not be explained based on quality assurance data (Additional file 2). Callister et al. (2006) used similar approaches when they compared central tendency, linear regression, locally weighted regression, and quantile techniques for normalizing and removing systematic biases from mass spectrometry and label-free proteomics data. In addition, Kimura et al. (2013) developed corrections to remove observed analytical biases from Sr-isotope concentrations measured in plagioclase crystals using laser ablation inductively coupled plasma mass spectrometry. Both uncorrected and corrected fin ray Sr:Ca data are published in Zigler et al. (2021) and presented in Additional file 1 to facilitate the reproducibility of analyses presented in this study and provide data not previously available for lake sturgeon in the Mississippi and St. Croix Rivers that can be used as a basis for comparison for data collected in any future studies. Additional research would be beneficial to verify relations between $\mathrm{Sr}: \mathrm{Ca}$ in water and lake sturgeon pectoral fin ray cross section for the St. Croix and Mississippi Rivers using controlled exposures (Phelps et al. 2012), determine the extent of movements between rivers, and identify reasons for movements between the rivers.

Results based on limited sample sizes in our exploratory study indicate some separation between lake sturgeon populations in the St. Croix and Mississippi Rivers, but these lake sturgeon populations do appear to be linked by movement of individual fish. Lake sturgeon typically use a variety of habitat types throughout their long lives, including spawning areas, juvenile rearing areas, overwintering areas, and adult feeding areas (Peterson et al. 2007). Auer (1996) suggested a barrier-free combined river and lake range of $250-300 \mathrm{~km}$ as a minimum distance to support self-sustaining lake sturgeon populations and suggested that distances of 750-1000 km would not be considered unusual. Currently, lake sturgeon in the St. Croix River and Navigation Pool 3 of the Mississippi River have access to $82 \mathrm{~km}$ of barrier-free habitat. Therefore, segmenting this already limited barrier-free habitat with a proposed invasive carp barrier at the mouth of the St. Croix River (Ad Hoc Asian Carp Task Force 2011) could negatively affect the St. Croix River lake sturgeon population by blocking the movement of adults into the Mississippi River in search of more favorable habitat, including food resources.
Invasion of Hypophthalmichthys spp. could alter aquatic food webs in the St. Croix River and cause further stress to the lake sturgeon population that already has poor growth indices and overall health relative to other sturgeon populations (Engel 1990; Ramsell 2010; Freedman et al. 2012). In newly invaded systems, bighead carp (Hypophthalmichthys nobilis) and silver carp (Hypophthalmichthys molitrix) can become biomass-dominant species and directly compete for food resources of native planktivores. For example, carp invasions have been shown to reduce body condition of some native fishes, such as bigmouth buffalo (Ictiobus cyprinellus) and gizzard shad, in the Illinois River (Irons et al. 2007) and have been experimentally shown to decrease the growth of paddlefish (Polyodon spathula, Schrank et al. 2003). Reduction of gizzard shad biomass could have substantial effects on lake sturgeon because gizzard shad can be a dominant prey species and source of carbon (Stelzer et al. 2008). Solomon et al. (2016) found that invasive carps likely also caused lower abundances of non-planktivorous species, including most sportfish and catostomids in a reach of the Illinois River. Reduced abundance of planktivorous species might be the result of reduced availability of food for larval fish (Solomon et al. 2016), although direct predation on larval fish may also be a factor in changes to native fish populations (Zhang et al. 2016). As indicated by a model of Pool 4 in the Mississippi River, the invasion of Hypophthalmichthys spp. may result in a 30\% initial decline in lake sturgeon biomass in the St. Croix River and Pool 3 of the Mississippi River (Kramer et al. 2019).

\section{Conclusions}

This study provides baseline data about health, trophic position, and migratory tendencies of lake sturgeon prior to establishment of (1) reproducing populations of invasive carps in the St. Croix and Mississippi Rivers (SACN and MISS NPS units, respectively), or (2) installation of barriers to prevent movement of fish between the St. Croix and Mississippi Rivers. Lake sturgeon captured from different locations had distinguishable fatty acid signatures, and stable isotope results demonstrated that lake sturgeon from the Mississippi River generally feed at a higher trophic level than lake sturgeon in the St. Croix River. However, samples sizes were insufficient to further address the influence of fish age or size on fatty acid composition. Therefore, the collection and analyses of tissue samples representing a broader range of year classes would help to develop a more robust fatty acid profile for lake sturgeon in the Mississippi and St. Croix Rivers.

Natal and capture location $\mathrm{Sr}: \mathrm{Ca}$ values measured in cross sections of lake sturgeon pectoral fin rays did not differ significantly within the same river $(p \geq 0.12)$, but 
Sr:Ca values were significantly different between rivers $(p<0.001)$. This indicates some degree of separation between the populations. However, laser ablation $\mathrm{Sr}: \mathrm{Ca}$ data from some fin ray cross sections also indicate that some lake sturgeon migrate between the St. Croix and Mississippi Rivers. Therefore, additional fin ray microchemistry and telemetry data would be useful for comparison to results of this exploratory study. Similar laser ablation techniques can also be used to study other migratory fish that serve as dispersal agents for at-risk mussel species, such as channel catfish (Ictalurus punctatus, Hove et al. 2000, U.S. Fish and Wildlife Service 2009). This study provides information that can be used by natural resource managers in the NPS and other agencies tasked with making decisions about strategies to maintain native fish populations and prevent invasive carps from establishing populations in the MISS and SACN NPS units. Finally, similar study approaches could be used to gather information about native fish species in other river systems that inform resource management decisions related to potential ecosystem disturbances, including colonization by invasive species.

\footnotetext{
Abbreviations

MISS: Mississippi National River and Recreation Area; SACN: Saint Croix National Scenic Riverway; Sr:Ca: Ratio of strontium to calcium; NPS: National Park Service; MNDNR: Minnesota Department of Natural Resources; EFA: Essential fatty acids; spp.: Multiple species of a single genus; Ca: Calcium; Sr: Strontium; Ba: Barium; USGS: U.S. Geological Survey; UMESC: Upper Midwest Environmental Sciences Center; FAME: Fatty-acid methyl esters; GC: Gas chromatograph; PLE: Pressurized liquid extraction; ASE: Accelerated solvent extraction; rpm: Revolutions per minute; $\mathrm{H}_{2} \mathrm{SO}_{4}$ : Sulfuric acid; ${ }^{13} \mathrm{C} /{ }^{12} \mathrm{C}$ : Ratio of stable isotopes of carbon based on atomic weights; ${ }^{15} \mathrm{~N} /{ }^{14} \mathrm{~N}$ : Ratio of stable isotopes of nitrogen based on atomic weights; $\delta^{13} \mathrm{C}$ : Stable isotopes of carbon with an atomic weight of $13 ; \delta^{15} \mathrm{~N}$ : Stable isotopes of nitrogen with an atomic weight of 15; VDPB: Vienna Pee Dee Belemnite; AIR: Internal standards for carbon and nitrogen used in analyses of stable isotopes; TL: Total length; ICPMS: Inductively coupled plasma mass spectrometry; UMASS EAF: University of Massachusetts-Boston Environmental Analytical Facility; MACS-3: Microanalytical reference material with composition similar to coral; cps: Counts per second; ${ }^{46} \mathrm{Ca}$ : Stable isotope of calcium with an atomic weight of 46 used as an internal standard for laser ablation analyses; ${ }^{43} \mathrm{Ca}$ : Stable isotope of calcium with an atomic weight of 43 used to quantify calcium concentrations in cross sections of lake sturgeon pectoral fin rays; ${ }^{86} \mathrm{Sr}$ : Stable isotope of strontium with an atomic weight of 86 used to quantify strontium concentrations in cross sections of lake sturgeon pectoral fin rays; i.e.: that is; a: Level of significance for statistical tests; ANOVA: Analysis of variance; HSD: Honestly significant difference; $r$ : Correlation coefficient; $p$ : Probability value used to determine statistical significance; LIN: Linoleic acid, C18:2n6c; ARA : Arachidonic acid, C20:4n6; EPA: Eicosapentaenoic acid, C20:5n3; DHA: Docosahexanenoic acid, C22:6n3; ALA: a-Linolenic acid, C18:3n3; SAFA: Saturated fatty acid; MUFA: Monounsaturated fatty acid; PUFA: Polyunsaturated fatty acid; D2: Capture location of lake sturgeon near Lock and Dam 2 on the Mississippi River; KN: Capture location of lake sturgeon near Kinnickinnic narrows on the St. Croix River; XL: Capture location of lake sturgeon near the Xcel Energy Plant on the St. Croix River; PC: Capture location of lake sturgeon near Prescott, Wisconsin, on the St. Croix River; F: F-statistic associated with testing statistical significance using analysis of variance; $d f$ : Degrees of freedom associated with testing statistical significance using analysis of variance; $R^{2}$ : Coefficient of determination; Cl: Confidence interval; SE: Standard error; dw: Dry weight, used to describe concentrations of fatty acids in lake sturgeon muscle tissues; DHA:EPA: Ratio of docosahexanenoic acid to eicosapentaenoic acid that often
}

correlates to growth rates; ${ }^{15} \mathrm{~N}$ : Stable isotope of nitrogen with an atomic weight of 15; FA: Fatty acid; C: Carbon; N: Nitrogen.

\section{Supplementary Information}

The online version contains supplementary material available at https://doi. org/10.1186/s13717-021-00344-y.

Additional file 1: Table S1. Morphometric data for lake sturgeon from the Mississippi and St. Croix rivers associated with boxplots presented in figure 3.

Additional file 2: Table S2. Calibration table for laser ablation inductivelycoupled plasma mass spectrometry analyses of cross sections from lake sturgeon pectoral fin rays.

Additional file 3. Raw data and summary files associated with laser ablation analyses of pectoral fin ray cross sections from lake sturgeon captured in the St. Croix and Mississippi Rivers.

Additional file 4: Table S4. Individual fish identifiers, river and fin ray portion combinations, and values of strontium-to-calcium ratios used in Figure 9 boxplots.

\section{Acknowledgements}

Pete Boma, Patty Ries, Will Gray, and Daniel Morell of the U.S. Geological Survey; Byron Karns, Michelle Prosser, and Jordan Wein of the National Park Service; and Joel Stiras of the Minnesota Department of Natural Resources aided in the field capture of lake sturgeon. Dr. Quinton Phelps of Missouri State University (formerly of the Missouri Department of Conservation and West Virginia University) coordinated staff to section and age sturgeon fin rays and conduct the laboratory analyses of trace elements.

\section{Authors' contributions}

JZ developed and coordinated the overall study, led analyses of fin ray laser ablation data, and led the writing of the final paper. SZ coordinated the submission of the funding proposal and led collection and review of field data with the assistance of RK. MB and LB led analyses and interpretation of fatty acid and stable isotope data and wrote corresponding methods, results, and discussion. SL led age analysis, preparation, and laser ablation analysis of collected pectoral fin rays and wrote the corresponding information in the Methods section. All authors read and approved the final manuscript.

\section{Funding}

This study was funded by the National Resource Preservation Program, a nation-wide collaborative program, supported by the USGS Ecosystems Mission Area, through which USGS and National Park Service staff address priority research needs identified by the National Park Service. National Park Service staff from the two National Park Service units represented in this study were involved in the development of the study proposal. The study proposal was reviewed and approved for funding by a panel of U.S. Geological Survey and National Park Service scientists.

\section{Availability of data and materials}

Data used in published analyses is available in a published U.S. Geological Survey data release at https://doi.org/10.5066/P9CBTOS9 (Zigler et al. 2021). Additional supporting information that describes data in the data release is provided in Additional files associated with this manuscript.

\section{Declarations}

\section{Ethics approval and consent to participate}

Results of all lake sturgeon tissue analyses presented in this study were obtained from nonlethally collected tissue samples in cooperation with State fisheries managers from the Minnesota Department of Natural Resources, and lake sturgeon were safely returned to the water following nonlethal collection of tissue samples. All animal procedures conducted by USGS staff were reviewed and approved by the U.S. Geological Survey's Upper Midwest Environmental Sciences Center Institutional Animal Care and Use Committee. 


\section{Consent for publication}

Any use of trade, firm, or product names is for descriptive purposes only and does not imply endorsement by the U.S. Government.

\section{Competing interests}

The authors declare that they have no competing interests.

\section{Author details}

${ }^{1}$ U.S. Geological Survey, California Water Science Center, 6000 J St, Placer Hall, Sacramento, CA 95819, USA. ${ }^{2}$ U.S. Geological Survey, Upper Midwest Water Science Center, 2280 Woodale Dr, Mounds View, MN 55112, USA. ${ }^{3}$ U.S. Geological Survey, Upper Midwest Environmental Sciences Center, 2630 Fanta Reed Road, La Crosse, WI 54603, USA. ${ }^{4}$ Division of Fisheries, Illinois Department of Natural Resources, 13608 Fox Road, Yorkville, IL 60560, USA.

Received: 23 July 2021 Accepted: 16 November 2021 Published online: 25 November 2021

\section{References}

Adams SM (1999) Ecological role of lipids in the health and success of fish populations. In: Arts MT, Wainman BC (eds) Lipids in freshwater ecosystems. Springer, New York

Ad Hoc Asian Carp Task Force (2011) Asian carp action plan: a plan to assess the threat posed by Asian carp and actions needed to minimize their impact in Minnesota. https://www.nps.gov/sacn/learn/nature/upload/ Asian-Carp-action-plan-11-2-2011-Final.pdf. Accessed 12 Feb 2021

Ahlgren G, Goedkoop W, Markensten H, Sonesten L, Boberg M (1997) Seasonal variation in food quality for pelagic and benthic invertebrates in Lake Erken: the role of fatty acids. Freshw Biol 38:555-570

Arts M, Brett M, Kainz M (2009) Lipids in aquatic ecosystems. Springer, New York

Asian Carp Regional Coordinating Committee (2020) Asian carp action plan for fiscal year 2020. http://asiancarp.us/Documents/2020-Action-Plan.pdf. Accessed 16 July 2021

Auer NA (1996) Importance of habitat and migration to sturgeons with emphasis on lake sturgeon. Can J Fish Aquat Sci 53:152-160

Baker RF, Blanchfield PJ, Paterson MJ, Flett RJ, Wesson L (2004) Evaluation of nonlethal methods for the analysis of mercury in fish tissue. Trans Am Fish Soc 133:568-576

Bruestle EL, Karboski C, Hussey A, Fisk AT, Mehler K, Pennuto C, Gorsky D (2019) Novel trophic interaction between lake sturgeon (Acipenser fulvescens) and non-native species in an altered food web. Can J Fish Aquat Sci 76:6-14. https://doi.org/10.1139/cjfas-2017-0282

Callister SJ, Barry RC, Adkins JN, Johnson ET, Qian W, Webb-Robertson B-JM, Smith RD, Lipton MS (2006) Normalization approaches for removing systematic biases associated with mass spectrometry and label-free proteomics. J Proteome Res 5:277-286. https://doi.org/10.1021/pr050300l

Crook DA, Gillanders BM (2006) Use of otolith chemical signatures to estimate carp recruitment sources in the mid-Murray River. Aust River Res App 22:871-879

DeVries DR, Frie RV (1996) Determination of age and growth. In: Murphy BR, Willis DW (eds) Fisheries techniques, 2nd edn. American Fisheries Society, Bethesda, pp 483-512

Elsdon TS, Gillanders BM (2004) Fish otolith chemistry influenced by exposure to multiple environmental variables. J Exp Mar Biol Ecol 313:269-284

Elsdon TS, Gillanders BM (2006) Identifying migratory contingents of fish by combining otolith $\mathrm{Sr}$ :Ca with temporal collections of ambient $\mathrm{Sr}: \mathrm{Ca}$ concentrations. J Fish Biol 69:643-657

Elsdon TS, Wells BK, Campana SE, Gillanders BM, Jones CM, Limburg KE, Secor DH, Thorrold SR, Walther BD (2008) Otolith chemistry to describe movements and life-history parameters of fishes: hypotheses, assumptions, limitations, and inferences. Ocean Mar Biol 46:297-330

Engel MP (1990) Population parameters of lake sturgeon in the St. Croix River with special reference to movements. Summary Report, Wisconsin Department of Natural Resources, $p 61$

Freedman JA, Butler SE, Wahl DH (2012) Impacts of Asian carps on native food webs. Final Project Report Illinois-Indiana Sea Grant, p 18

Fritts AK, Knights BC, Lafrancois TD, Vallazza JM, Bartsch LA, Bartsch MR, Richardson WB, Bailey SW, Kreiling RM, Karns BN (2018a) Evaluating potential effects of bigheaded carps on fatty acid profiles of multiple trophic levels in large rivers of the Midwest, USA. Food Webs. https:// doi.org/10.1016/j.fooweb.2018.e00095

Fritts AK, Knights BC, Lafrancois TD, Bartsch LA, Vallazza JM, Bartsch MR, Richardson WB, Karns BN, Bailey SW, Kreiling RM (2018b) Spatial and temporal variance in fatty acid and stable isotope signatures across trophic levels in large river systems. River Res App 34:834-843. https:// doi.org/10.1002/rra.3295

Gover TR, Nims MK, Van Tassell JJ, Collingsworth PD, Olesik JW, Ludsin SA, Marschall EA (2014) How much cleaning is needed when processing otoliths from fish larvae for microchemical analysis? Trans Am Fish Soc 143:779-783. https://doi.org/10.1080/00028487.2014.889749

Guay CK, Falkner KK (1998) A survey of dissolved barium in the estuaries of major Arctic rivers and adjacent seas. Cont Shelf Res 18:859-882

Gutreuter S, Vallazza JM, Knights BC, Bartsch MR, Bartsch LA, Richardson WB (2011) Early evidence of effects of invasive Asian carps on selected fishes of the Upper Mississippi River System. Project completion report to the U.S. Fish \& Wildlife Service, project number 3210APN11. U.S. Geological Survey, Upper Midwest Environmental Sciences Center, La Crosse, Wisconsin

Hecky RE, Hesslein RH (1995) Contributions of benthic algae to lake food webs as revealed by stable isotope analysis. J N Am Benthol Soc 14:631-653

Hove MC, Hillegass KR, Kurth JE, Pepi VE, Lee CJ, Knudsen KA, Kapuscinski AR, Mahoney PA, Bomier MM (2000) Considerations for conducting host suitability studies. In: Tankersley RA, Warmolts DI, Watters GT, Armitage BJ, Johnson PD, Butler RS (eds) Proceedings of the Conservation, Captive Care, and Propagation of Freshwater Mussels. Ohio Biological Survey, Columbus. pp 27-34

Hung SSO (2017) Recent advances in sturgeon nutrition. Anim Nutr 3:191-204. https://doi.org/10.1016/j.aninu.2017.05.005

Humston R, Priest BM, Hamilton WC, Bugas PE (2010) Dispersal between tributary and main-stem rivers by juvenile smallmouth bass evaluated using otolith microchemistry. Trans Am Fish Soc 139:171-184

Irons KS, Sass GG, McClelland MA, Stafford MA (2007) Reduced condition factor of two native fish species coincident with invasion of nonnative Asian carps in the Illinois River, U.S.A. Is this evidence for competition and reduced fitness? J Fish Biol 71:258-273

Jardine TD, Kidd KA, Fisk AT (2006) Applications, considerations, and sources of uncertainty when using stable isotope analysis in ecotoxicology. Environ Sci Technol 40:7501-7511

Kimura J-I, Takahashi T, Chang Q (2013) A new analytical bias correction for in situ Sr isotope analysis of plagioclase crystals using laser-ablation multiple-collector inductively coupled plasma mass spectrometry. J Anal Spectrom 28:945-957. https://doi.org/10.1039/C3JA30329B

Kramer NW, Phelps QE, Pierce CL, Colvin ME (2019) A food web modeling assessment of Asian Carp impacts in the Middle and Upper Mississippi River, USA. Food Webs. https://doi.org/10.1016/j.fooweb.2019.e00120

Minnesota Department of Natural Resources (MNDNR) (2021) Rare species guide: Acipenser fulvescens. https://www.dnr.state.mn.us/rsg/profi le.html?action=elementDetail\&selectedElement=AFCAA01020. Accessed 12 Feb 2021.

Nickum JG, Bart Jr HL, Bowser PR, Greer IE, Hubbs C, Jenkins JA, MacMillan JR, Rachlin JW, Rose JD, Sorensen PW, Tomasso JR (2004) Guidelines for the use of fishes in research.

Ott RL, Longnecker M (2010) An introduction to statistical methods and data analysis, 6th edn. Cengage Learning, Boston

Palmer MR, Edmond JM (1992) Controls over strontium isotope composition of river water. Geochim Cosmochim Acta 56:2099-2111

Peterson DL, Vecsei P, Jennings CA (2007) Ecology and biology of the lake sturgeon: a synthesis of current knowledge of a threatened North American Acipenseridae. Rev Fish Biol Fisheries 17:59-76

Phelps QE, Whitledge GW, Tripp SJ, Smith KT, Garvey JE, Herzog DP, Ostendorf DE, Ridings JW, Crites JW, Hrabik RA, Doyle WJ, Hill TD (2012) Identifying river of origin for age-0 Schaphirhynchus sturgeons in the Missouri and Mississippi Rivers using fin ray microchemistry. Can J Fish Aq Sci 69:930-941

Pikitch EK, Doukakis P, Lauck L, Charkrabarty P, Erickson DL (2005) Status, trends and management of sturgeon and paddlefish fisheries. Fish Fish 6:233-265 
Porreca AP, Hintz WD, Whitledge GW, Rude NP, Heist EJ, Garvey JE (2016) Establishing ecologically relevant management boundaries: linking movement ecology with the conservation of Scaphirhynchus sturgeon. Can J Fish Aq Sci 73:877-884

Pracheil BM, Hogan JD, Lyons L, McIntyre PB (2014) Using hard-part microchemistry to advance conservation and management of North American freshwater fishes. Fisheries 39:451-465

R Core Team (2014) R: A language and environment for statistical computing. R Foundation for Statistical Computing, Vienna, Austria. http://www.Rproject.org/.

Ramsell R (2010) A population assessment of the lake sturgeon in the lower St. Croix River. Progress Report, Minnesota Department of Natural Resources. $9 \mathrm{pp}$.

Schiller M, Bizzarro M, Paton C (2012) Calcium isotope measurement by combined HR-MC-ICPMS and TIMS. J Anal Spectrom 27:38-49. https://doi.org/ 10.1039/C1JA10272A

Schrank SJ, Guy CS, Fairchild JF (2003) Competitive interactions between age-0 bighead carp and paddlefish. Trans Am Fish Soc 132:1222-1228

Smith A, Smokorowski K, Marty J, Power M (2016) Stable isotope characterization of Rainy River, Ontario, lake sturgeon diet and trophic position. J Gt Lakes Res 42:440-447

Solomon LE, Pendleton RM, Chick JC, Casper AF (2016) Long-term changes in fish community structure in relation to the establishment of Asian carps in large floodplain river. Biol Invas 18:2883-2895

Stelzer RS, Drecktrah HG, Shupryt MP, Bruch RM (2008) Carbon sources for lake sturgeon in Lake Winnebago, Wisconsin. Trans Am Fish Soc 137:1018-1028

Surge DM, Lohmann KC (2002) Temporal and spatial differences in salinity and water chemistry in SW Florida estuaries: effects of human-impacted watersheds. Estuaries 25:393-408

Tocher DR (2003) Metabolism and functions of lipids and fatty acids in teleost fish. Rev Fish Sci 11:107-184

U.S. Fish and Wildlife Service (2009) Winged mapleleaf: Quadrula fragosa. Fact Sheet, 2 pp. https://www.fws.gov/midwest/endangered/clams/pdf/ wmapleleaf.pdf.

U.S. Geological Survey (2016) USGS water data for the Nation: U.S. Geological Survey National Water Information System database, accessed September 30, 2016 https://doi.org/10.5066/F7P55KJN.

Vander Zanden MJ, Shuter BJ, Lester NP, Rasmussen JB (2000) Within- and among-population variation in the trophic position of a pelagic predator, lake trout (Salvelinus namaycush). Can J Fish Aq Sci 57:725-731

Wells BK, Rieman BE, Clayton JL, Horan DL, Jones CM (2003) Relationships between water, otolith, and scale chemistries of west slope cutthroat trout from the Coeur d'Alene River, Idaho: the potential application of hard-part chemistry to describe movements in freshwater. Trans Am Fish Soc 132:409-424

Whitledge GW, Knights B, Vallazza J, Larson J, Weber MJ, Lamer JT, Phelps QE, Norman JD (2019) Identification of Bighead Carp and Silver Carp early-life environments and inferring Lock and Dam 19 passage in the Upper Mississippi River: insights from otolith chemistry. Biol Invasions 21:1007-1020

Williams MCW, Schrank C, Anderson HA (2014) Fatty acids in thirteen Wisconsin sport fish species. J Gt Lakes Res 40:771-777

Williams MCW, Murphy EW, McCarty HB, Snyder BD, Schrank CS, McCann PJ, Crimmins BS (2017) Variation in the essential fatty acids EPA and DHA in fillets of fish from the Great Lakes region. J Gt Lakes Res 43:150-160

Wilson SA, Koenig AE, Orklid R (2008) Development of microanalytical reference material (MACS-3) for LA-ICP-MS analysis of carbonate samples. Geochim Cosmochim Acta 72(12):A1025

Zhang $\mathrm{H}$, Rutherford ES, Mason DM, Breck JT, Wittmann ME, Cooke RM, Lodge DL, Rothlisberger JD, Zhu X, Johnson TB (2016) Forecasting the impacts of silver and bighead carp on the Lake Erie food web. Trans Am Fish Soc 145:136-162

Ziegeweid JR, Zigler SJ, Maki RP, Karns BN, Love SA (2018) Method comparisons for determining concentrations of metals in water samples used in studies of fish migratory histories. U.S. Geological Survey. Sci Investig Rep 1:11. https://doi.org/10.3133/sir20185143

Zigler SJ, Ziegeweid JR, Bartsch MR, Bartsch LA, Kennedy R, Love S (2021) Age, Trace Metal, Stable Isotope, and Fatty Acid Data Collected from Sturgeon Captured in the Mississippi and St. Croix Rivers, Minnesota and Wisconsin, 2015-2016. U.S. Geological Survey data release, https://doi.org/10.5066/ P9CBTOS9

\section{Publisher's Note}

Springer Nature remains neutral with regard to jurisdictional claims in published maps and institutional affiliations.

\section{Submit your manuscript to a SpringerOpen ${ }^{\circ}$ journal and benefit from:}

- Convenient online submission

- Rigorous peer review

- Open access: articles freely available online

- High visibility within the field

- Retaining the copyright to your article

Submit your next manuscript at $\boldsymbol{\nabla}$ springeropen.com 